HOUSING THE DEAD IN A NO VACANCY CITY:

AN ANALYSIS OF BEST PRACTICES IN PURSUIT OF TORONTO'S CEMETERY DESIGN AND PLANNING FRAMEWORK

by

Sybil Tong
H.B.A., University of Toronto, 2017

A Major Research Paper

presented to Ryerson University

in partial fulfillment of the requirements for the degree of

Master of Planning

in

Urban Development

Toronto, Ontario, Canada, 2019

(C) Sybil Tong 2019 


\section{Author's Declaration}

I hereby declare that I am the sole author of this MRP. This is a true copy of the MRP, including any required final revisions.

I authorize Ryerson University to lend this paper to other institutions or individuals for the purpose of scholarly research.

I further authorize Ryerson University to reproduce this MRP by photocopying or by other means, in total or in part, at the request of other institutions or individuals for the purpose of scholarly research.

I understand that my MRP may be made electronically available to the public. 


\title{
HOUSING THE DEAD IN A NO VACANCY CITY: \\ AN ANALYSIS OF BEST PRACTICES IN PURSUIT OF TORONTO'S CEMETERY DESIGN AND PLANNING FRAMEWORK
}

\author{
(C) Sybil Tong, 2019 \\ Master of Planning \\ in \\ Urban Development \\ Ryerson University
}

\begin{abstract}
As Toronto runs out of burial space, there currently lacks a set of guidelines to direct the cemetery planning process. This paper explores the barriers in the cemetery planning process that have manifested in Toronto and the planning ramifications of alternatives to casket burials, such as cremation, green burials, and grave reuse. This analysis aims to examine the specific solutions taken by various cities considering their physical geography and the population's cultural and religious practices. The purpose of these analyses is to identify which methods of cemetery design and alternative interment, if any, would be feasible in Toronto's context with regards to environmental sustainability, cultural practices, and affordability.
\end{abstract}

Key words:

cemeteries; Toronto; sustainability; land use 


\section{ACKNOWLEDGEMENTS}

I would like to acknowledge and express my sincere gratitude to the various

professionals who took the time to be interviewed for this project; without their insights and continued feedback and encouragement, this project would not have reached the level of breadth and detail that it has.

I would also like to thank the following individuals for their help throughout this project:

My supervisor, Dr. Shelagh McCartney, for her knowledge and guidance.

Nicole Hanson for her expertise, mentorship and empowerment.

My colleagues at the Ryerson School of Urban and Regional Planning for the laughs, camaraderie, and inspiration. It was a privilege to learn from and with you all throughout the last two years.

Lastly, my family and friends for their continued love and support throughout the completion of my studies. 
"The cemetery is an open space among the ruins...

It might make one in love with death,

to think that one should be buried in so sweet a place."

- Percy Bysshe Shelley, Adonais 


\section{Table of Contents}

1.0 Introduction 1

1.1 Purpose 1

1.2 Method 3

1.2.1 Case Study 3

1.2.3 Interviews 5

1.3 Paper Structure $\quad 6$

2.0 The Cemetery Planning Process $\quad 7$

$\begin{array}{ll}2.1 \text { History } & 7\end{array}$

$\begin{array}{ll}2.2 \text { Regulation } & 10\end{array}$

2.2.1 Zoning and Policy 10

2.2.2 Funding 13

$\begin{array}{ll}2.2 .3 \text { Governance } & 14\end{array}$

2.3 Considerations and Challenges 15

2.3.1 Land Constraints \& Environmental Sustainability 15

2.3.2 Social Equity 17

2.3.3 Lack of a Planning Framework 18

$\begin{array}{ll}3.0 \text { Case Study } & 21\end{array}$

3.1 Vertical Cemeteries: Cremation and Columbaria 21

3.1.1 Hong Kong $\quad 22$

3.1.2 New Delhi 26

3.2 Green Burials and Landscaped Cemeteries 28

3.2.1 Berlin 30

3.2.2 Taipei 31

3.3 Grave Exhumation and Reuse 34

3.3.1 London 36

$\begin{array}{ll}3.3 .2 \text { Singapore } & 37\end{array}$

3.4 Discussion 39

$\begin{array}{ll}4.0 \text { Recommendations } & 42\end{array}$ 
4.1 Policy Amendments $\quad 42$

4.2 Green Incentive Program 43

4.3 Cemetery Design and Public Engagement $\quad 44$

4.4 Cemetery Sustainability $\quad 45$

5.0 Conclusion $\quad 46$

$\begin{array}{ll}\text { 6.0 Appendices } & 48\end{array}$

Appendix 1. Map of Toronto's Cemeteries 48

Appendix 2. Subject Matter Expert Interview Questions 49

$\begin{array}{ll}7.0 \text { Bibliography } & 50\end{array}$

Images $\quad 57$ 


\section{LIST OF APPENDICES}

Appendix 1. Map of Toronto's Cemeteries

Appendix 2. Subject Matter Expert Interview Questions 


\subsection{Introduction}

Every culture and society has customs and traditions surrounding death. From heritage buildings to monuments, the desire to memorialize and commemorate the past, including our dead, is a process that cannot be divorced from placemaking practices. Cemeteries, as a commemorative space, are for the living as well as the dead: they provide a perpetual dedicated space for memorializing loved ones who have passed. More than a site for burials and funerals, the cemetery is a political space of interpretation, collective memory, and fulfills a deep social need to remember and honour the deceased. Yet despite the criticality of burial grounds, cemeteries are often overlooked by municipalities and planners as a land use to be planned for in the planning process. As a result, cemeteries have become the locus of multiple intersecting issues of equity and environmental sustainability. Cultural anxieties associated with death in the planning profession may be a factor contributing to the underrepresentation of cemeteries in mainstream planning discourse and practice. However, with many cities rapidly running out of burial space, due to scarcity of land, the aging population, and increasing development (Basmajian \& Coutts, 2010), citybuilders and policymakers cannot afford to keep putting cemeteries on the backburner. Planning for complete communities includes planning the spaces in which we and future generations will live, play, work, and die.

\subsection{Purpose}

In 2016, the City of Toronto called for a Cemetery Needs Analysis as a response to the York Region Cemetery Needs Analysis Policy Framework Report to develop a policy framework for the city's cemeteries. The intent for the City of Toronto was to provide 
an overview of current municipal interment capacity, project future cemetery demand, and recommend a strategy for the expansion of cemetery use within the city. The need for such a policy framework was attributed to the lack of burial space projected for the next decade (City of Toronto, 2016). In particular, there was concern that the constraints on land would cause "economic and social hardship" (City of Toronto, 2016) for Toronto residents as they may have to resort to looking far outside of the Greater Toronto Area for burial space for their loved ones. As of the time of writing of this paper, the City of Toronto's Cemetery Needs Analysis has not been completed and released.

The lack of clear guidelines to direct the cemetery planning and design process is not unique to Toronto or North American cities. Given the constraints on available burial lands, the future of cemetery planning in many cities is unclear (Coutts, Basmajian, \& Chapin, 2011; Chen \& Yang, 2015). While addressing this uncertainty, it will be necessary for cities to develop planning frameworks in the form of Official Plans, Secondary Plan, Precinct Plans, and master plans that include physical design guidelines, strategies for public participation, and policies that hold regard for diverse cultural needs, environmental sustainability, and the decreasing capacity of available land. As planners are mandated to plan in the public interest for affordable and sustainable communities for increasingly diversifying communities, so, too, should cemeteries be planned with the same considerations in mind.

This paper will propose alternative burial methods in response to the lack of burial lands and assess the feasibility of these options in order to make recommendations for the design and planning of Toronto's cemeteries for future generations. In the pursuit of a holistic cemetery planning framework, it will be necessary to consider these alternative 
solutions, understand their implications, increase public awareness, and if need be, facilitate the use of these methods through amendments to Official Plans and zoning bylaws or updated design principles. For the purposes of this paper, alternative interment practices will refer to methods of interring human remains outside of the traditional full casket burial, such as cremation, green burials, and grave reuse ${ }^{1}$. It is important to clarify that these methods are neither new nor uncommon (for example, cremation rates have been on the rise in recent decades and are predicted to continue on this upward trend (Basmajian \& Coutts, 2010; Bennett \& Davies, 2015)). However, these are alternatives to full casket burials, which, as the method that demands the most space within a cemetery at almost $5.4 \mathrm{~m}^{2}$ per plot (after accounting for necessary cemetery infrastructure such as roads) (personal communication, 2019), is now inaccessible for many due to the lack of available space.

\subsection{Method}

\subsubsection{Case Study}

This paper will draw upon an analyses of six cities with alternative interment practices that vary based on the city's physical geography, land availability, and cultural and religious traditions of the population. The purpose of these analyses is to examine the success of these solutions in their ability to meet interment demand, satisfy the

\footnotetext{
${ }^{1}$ Discussions of alkaline hydrolysis (also known as resomation, bio-cremation or water cremation) will be excluded from the scope of this paper. Alkaline hydrolysis is still a relatively new method of handling human remains, and as such, there are no salient precedents of this being conducted on a large-scale to inform this discussion. Moreover, it will be difficult to predict public reception to this method in the future.
} 
requirements of different groups, and ultimately, how well these methods can sustain future need as land continues to become scarce. Based on these measures, this research intends to identify which practices of cemetery design and/or interment could be adapted in Toronto; in so doing, this analysis aims to form a set of best practices that can be assessed for their feasibility in Toronto's land use context. This feasibility study will adopt a triple bottom line lens to analyze these methods for their economic viability, ecological sustainability, and effects on social equity.

Two cities were chosen for each interment method to be evaluated. Each pair of cities shares in common with Toronto a high population density and a land scarcity issue but differs in characteristics associated with their respective geocultural region, such as culture, religion, politics, and socioeconomic disparity. By examining the interment methods across these lines of difference, it is the goal of this case study to identify the factors that lend to their effectiveness (or ineffectiveness). Summarized in the table below, the case study will assess cremation in Hong Kong and New Delhi; green burials in Berlin and Taipei; and grave reuse in London and Singapore. Though there is some overlap between interment methods amongst the cities in the case study, the cities were chosen to showcase successful examples of each practice. 
Table 1. Case Study: Cities at a glance ${ }^{2}$

\begin{tabular}{|c|c|c|c|c|}
\hline City & $\begin{array}{c}\text { Geocultural } \\
\text { Region }\end{array}$ & $\begin{array}{c}\text { Population } \\
\text { Density } \\
\text { (per sq. } \\
\text { km) }\end{array}$ & $\begin{array}{c}\text { Main Religion by } \\
\text { Population }\end{array}$ & $\begin{array}{c}\text { Interment } \\
\text { Method }\end{array}$ \\
\hline $\begin{array}{c}\text { Toronto } \\
\text { (GTA) }\end{array}$ & North America & 4149.5 & Christianity (54\%) & - \\
\hline Hong Kong & East Asia & 6785.1 & Atheist/Agnostic (80\%) & Cremation \\
\hline Delhi & South Asia & $29,259.1$ & Hinduism (82\%) & Cremation \\
\hline Berlin & Europe & 3809.0 & Atheist/Agnostic (60\%) & Green Burial \\
\hline Taipei & Southeast Asia & 9952.1 & Buddhism (35\%) & Green Burial \\
\hline London & Europe & 5601.0 & $\begin{array}{c}\text { Christianity (48\%) } \\
\text { Grave } \\
\text { Reuse }\end{array}$ \\
\hline Singapore & Southeast Asia & 8264.9 & $\begin{array}{c}\text { Buddhism/Taoism } \\
(43 \%)^{3}\end{array}$ & $\begin{array}{c}\text { Grave } \\
\text { Reuse }\end{array}$ \\
\hline
\end{tabular}

\subsubsection{Interviews}

Semi-structured interviews (Appendix 2) were conducted with professionals involved in the planning, design, and regulation of cemeteries in Canada. As will be discussed in Section 2.3.2, the existing academic literature around cemetery planning, especially for the North American planning context, is sparse; as such, these interviews provided first-hand insight to bridge some of the gaps. In particular, the professionals were asked to speak to the cemetery planning process and the current trends and barriers that exist within it, and any considerations being made toward equitable, sustainable planning and design in a land-constrained environment.

2 Source: Compiled from World Population Review, 2018

3 Department of Statistics Singapore. (2018, May 09). Retrieved from https://www.singstat.gov.sg/-/media/files/visualising data/infographics/ghs/highlights-ofghs2015.pdf 


\subsection{Paper Structure}

The first chapter of this paper sets up the purpose and methodology of the undertaking of this study, specifically with regards to the cemetery land crisis that Toronto and many cities are confronted with regarding the future of burial grounds. The second chapter will further explore the history of cemeteries in North America and provide an overview of the cemetery planning process, from the regulation and financing to multiple factors that inform the design and planning of this land use. The third chapter is a case study of six cities which, like Toronto, are faced with constraints on available burial land. Based on this case study, Chapter Four will set forth policy and design recommendations for the future of Toronto's cemetery planning framework. Lastly, the fifth chapter will conclude with a summary and final remarks. 


\subsection{The Cemetery Planning Process}

\subsection{History}

The practice of designing large landscaped cemeteries emerged from Britain and the United States in the 1830s, though for much of the 19th century, formal burials in North America took place in church graveyards. As populations grew and towns densified into cities, burial grounds were relocated from church grounds to the outer fringes of new urban centres (Finney, 2012). In addition to freeing up valuable land and infrastructure for generators of economic growth such as residential, industrial, and commercial development (Bennett \& Davies, 2015), this was also a public health decision. In East London, burial grounds were transformed into sprawling gardens and playgrounds, with the purpose of creating open green spaces amongst the rapid industrialization to promote physical and mental health (Finney, 2012; Brown, 2013). The rural cemetery movement, inspired by British gardening, brought idyllic landscapes to the outskirts of American cities. In so doing, cemeteries became the first urban park, providing urban dwellers with quiet, beautifully landscaped spaces where families and individuals could picnic or escape the grime of the city to find quiet and solitude (Finney, 2012). 


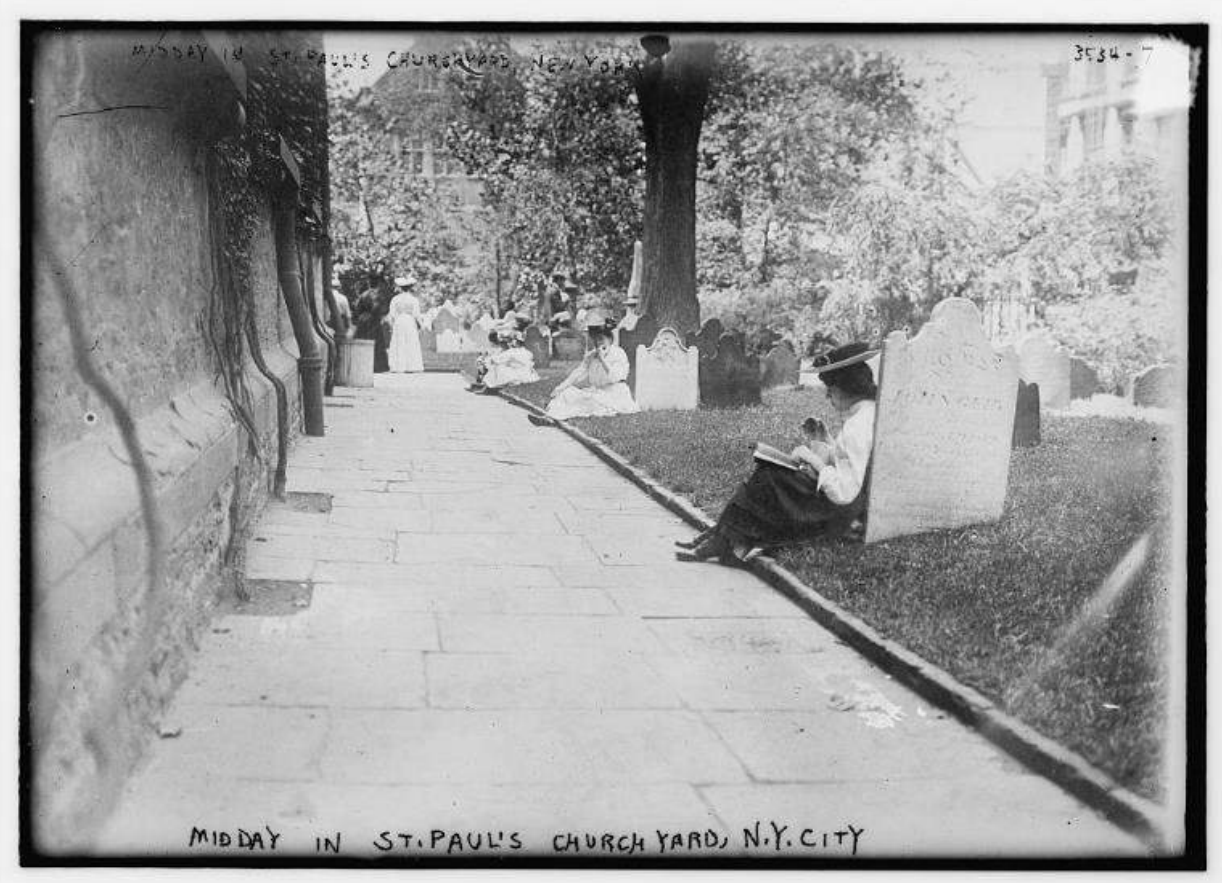

Above: Mid-day in St. Paul's Churchyard, New York City. A woman sits resting against a tombstone with a book.

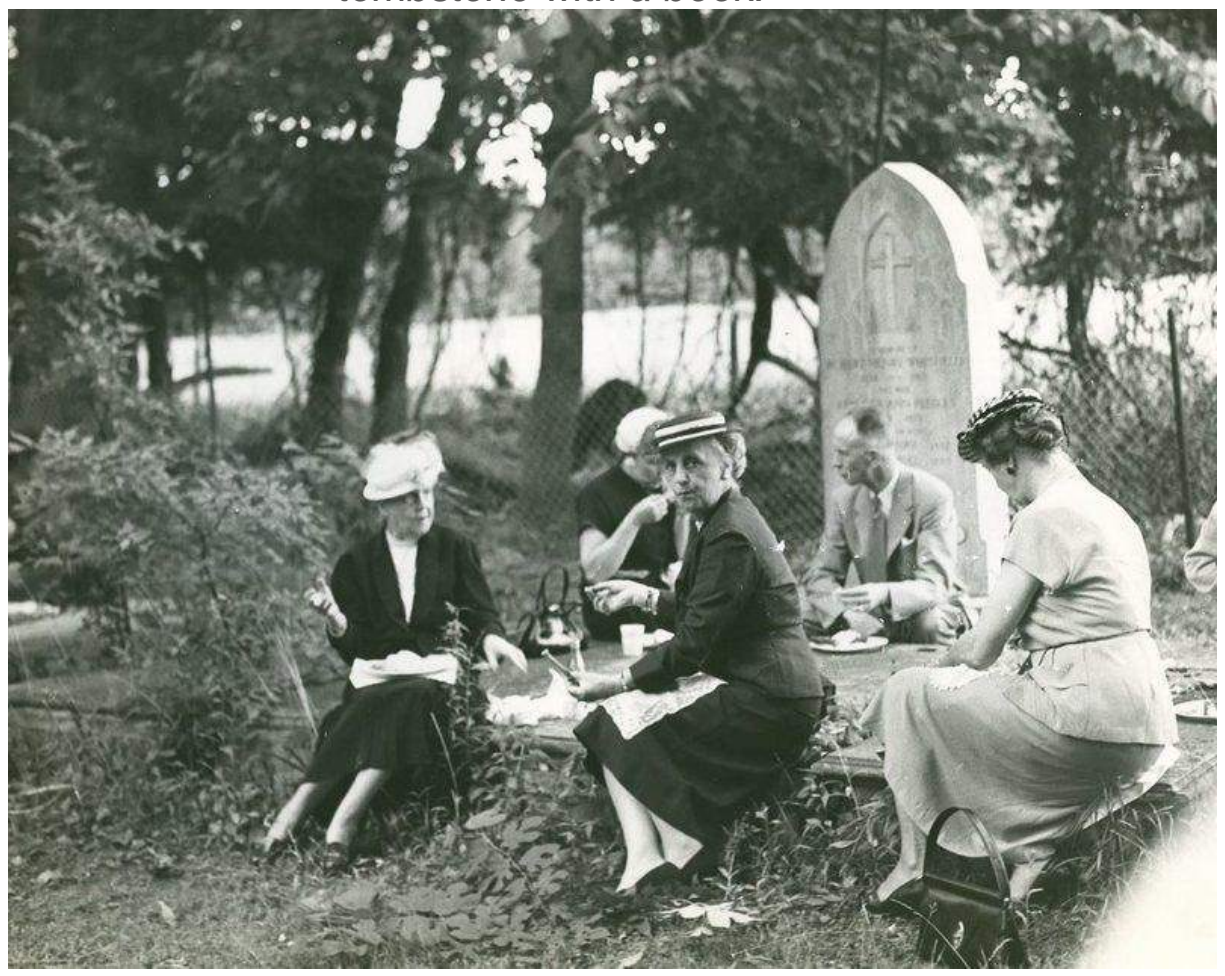

Above: A picnic amongst the tombstones. 
While cemetery parks were gaining popularity in America, Toronto, as a colonial centre, was still catching up to its neighbours south of the border. Unlike some American cities, Toronto did not yet face issues of overcrowding in cemeteries; however, while Anglicans and Roman Catholics had adequate space for appropriate burials, people outside of these groups were prohibited from burying their dead (Coutts, 1986). This disparity led to the formation of the Toronto General Burying Grounds Trust in 1825. In 1826, the Trust purchased land in Yorkville for the establishment of Potter's Field, Toronto's first non-denominational cemetery. Following petitions from the residents of Yorkville, who felt that the cemetery was slowing the pace of development in the village, the facility was closed and those who were buried there were re-interred, mostly in the Toronto Necropolis in Cabbagetown (Coutts, 1986, p. 8). The Trust sold the land to the south of Necropolis, which was originally intended for the expansion of the cemetery, to the City and purchased 200 acres for $\$ 20,000$ in 1873 to build Mount Pleasant Cemetery. The following year, the Trust hired a landscape architect to develop the plans for the cemetery, with the goal of establishing an urban sanctuary much like those in the States, with curved trails, ponds, and numerous types of trees and plants (Coutts, 1986, p.10).

By the late 19th century, the formation of suburbs softened the line between the realms of urban and rural. At the same time, the proliferation of parks replaced cemeteries as outdoor leisure spaces (Finney, 2012), effectively ending the culture of visiting cemeteries for respite and recreation. 


\subsection{Regulation}

\subsubsection{Zoning and Policy}

The history of Potter's Field in Yorkville exemplifies the frictions that has existed between development and burial grounds. As cities expanded, development occurred around cemeteries, such that older cemeteries, once at the edges of the city, are now surrounded by residential, industrial, and commercial development. Several scholars discuss the benefits of integrating cemeteries into the urban fabric and encouraging public use, reframing cemeteries as open space that provides a public service in addition to their primary function (Lehrer, 1974; Benjamin \& Coutts, 2010; Campo-Ruiz, 2015; Chen \& Yang, 2015; Bennett \& Davies, 2016). Many modern urban cemeteries have incorporated design elements such as botanical gardens, green space preserves, and memorial parks that attempt to revive the cemetery as open spaces meant for use outside of funerals and mourning. The current trustees of Mount Pleasant Cemetery continue to promote recreational use of the space (Coutts, 1986). While the cemetery has no official designation as a multi-use space, the site frequently accommodates passive recreation such as jogging and dog-walking. However, without "detailed, systematic, and scientific design guidelines" (Chen \& Yang, 2015, p. 57) to inform cemetery design, it will be difficult to encourage future cemeteries to continue accommodating such uses without taking up valuable land that would serve the primary purpose of interment.

Cemeteries do not fit neatly within most basic zoning categories in Ontario's land use policy: while Toronto zones cemeteries as Open Space (City of Toronto, 2017), some municipalities permit cemeteries in lands designated for Open Space/Parkland, 
Institutional, Agricultural, or a combination of the above. Few municipalities, such as Whitchurch-Stouffville and Uxbridge, designate Cemeteries as a land use designation of their own (Larkin, 2011, p. 64). It is important to note that there is no official definition of "cemetery" or classification of the various land uses that can occur within cemeteries. Under the Official Plan and the Cemeteries Act (1990), any land allocated to interment is referred to as a cemetery; there is no legislative framework that differentiates land for columbaria from land for scattering grounds from land for green burials (Larkin, 2011, p.22). Therefore, Ontario planning legislation as it currently exists does not recognize or support alternatives to full casket burials as a land use.

The 2014 Provincial Policy Statement ("PPS") includes a singular reference to the development of cemeteries as a key part of a complete community:

S. 1.1.1 Healthy, liveable and safe communities are sustained by:

b) accommodating an appropriate range and mix of residential (including second units, affordable housing and housing for older persons), employment (including industrial and commercial), institutional (including places of worship, cemeteries and long-term care homes), recreation, park and open space, and other uses to meet long-term needs;

Prior to this amendment, the PPS did not recognize institutional uses such as cemeteries as necessary elements of a community. In the 2005 Provincial Policy Statement, the only mention of cemeteries was as an example of "Cultural Heritage Landscapes". Despite this consideration, subsequent planning documents have not made specific mention to cemeteries. For this reason, most municipal Official Plans are not consistent with the Provincial Policy Statement, which is to be read and implemented in its entirety in planning as a practice. 
Similarly, the Growth Plan for the Greater Golden Horseshoe (2017), which provides policies to guide growth and intensification, contains no direct reference to the development of cemeteries outside of an amendment which included the definition of Cultural Heritage Landscapes, taken from the 2014 PPS.

The Oak Ridges Moraine Conservation Plan (2002) (“ORMCP”) guides regional and municipal planning within the Oak Ridges Moraine with a focus on ecological management and limiting land use conversion or development in sensitive rural areas. As the study area is encircled by the Oak Ridges Moraine, the ORMCP places limits on any development or expansion of the GTA, including its cemeteries. Under this Plan, there are no policies that inform the development of the large urban cemeteries that have been the focus of this paper. However, "small-scale" cemeteries are a permitted use in rural lands; though there is no formal definition of "small-scale cemetery", these are burial grounds that are primarily intended to serve local residents.

S. 40. (1) Small scale commercial, industrial and institutional uses,

(c) include, but are not limited to,

(iii) schools, places of worship, community halls, retirement homes, and cemeteries intended mainly to serve nearby Rural Settlements within the Plan Area.

Lastly, the Greenbelt Plan (2017) dictates that cemeteries are a supported use in rural lands of the Protected Countryside as well as a defined cultural heritage landscape. Informed by the 2014 Provincial Policy Statement, the references to cemeteries were added as amendments to the 2005 Greenbelt Plan (which contained no mention of cemeteries) that became effective on June 1, 2017.

\section{S. 3.1.4 Rural Lands Policies}


For lands falling within rural lands of the Protected Countryside, the following policies shall apply:

Rural lands support and provide the primary locations for a range of recreational, tourism, institutional (including cemetery) and resource-based commercial/ industrial uses...

Similar to the ORMCP, the Greenbelt Plan sets forth policies relating to the protection of agricultural land and natural resources. In particular, the Plan prohibits the rezoning of the Greenbelt from its current Agricultural designation. Given that only four municipalities in the GTA zone cemeteries as Agricultural (Larkin, 2011, p. 64), the Greenbelt Plan further limits the development of cemeteries in the areas surrounding the GTA.

\subsubsection{Funding}

The income required for cemetery maintenance and upkeep, known as perpetual care, is primarily funded through taxes for municipally-run sites and investments for privately-run sites. In either case, income can be generated through plot sales, most of which occur before immediate need, such as in the case of the passing of a spouse (Relyea, 2013). In 1955, an Ontario law required that $40 \%$ of the purchase price of a burial plot, $20 \%$ of a cremation plot, and $15 \%$ of a columbarium niche must be dedicated to perpetual care, with the rest treated as revenue (Belford, 2018; Desmond, 2013). These fees include weeding, mowing, maintenance of flower beds, marker resetting, and other maintenance as required.

Before a cemetery can be licensed, the operator must also establish a Care and Maintenance Fund. As of 1992, the cemetery owner or operator must put $\$ 100000$ into the fund, which grows as the operator sells interment rights (Bereavement Authority of 
Ontario, 2019). The bulk of the budget for cemetery maintenance is devoted toward lawn upkeep. Weeds and inclement weather present complications for mowing, which is in itself a labour-intensive task that requires a high level of attention to carefully trim around grave markers. However, perpetual care in large cemeteries can fall short of the basic requirements that visitors of cemeteries would expect, as the priority of cemetery operators is to complete burials rather than to maintain upkeep (Desmond, 2013).

\subsubsection{Governance}

In Ontario, the bereavement sector, including funeral establishments, cemetery operators, and sales representatives are overseen by the Bereavement Authority of Ontario ("BAO"), a non-profit, non-governmental delegated admistrative authority established in 2016 by the Ministry of Government and Consumer Services Cemeteries and Crematoriums Regulation Unit (hereinafter referred to as the "Ministry") to administer the Funeral, Burial, and Cremation Services Act, 2002 (FBCSA). The FBCSA regulates cemeteries, crematoria, funeral establishments and directors, the sales and transfer of cemeteries, and the various staff involved. This does not include the closing of cemeteries as the legislation relating to cemetery closures and war graves was retained under the jurisdiction of the Ministry (Bereavement Authority of Ontario, 2019). If a cemetery is deemed abandoned or unable to be maintained, the municipality or the province will take ownership of the cemetery and assumes all assets, rights, and responsibilities to the land (Ministry of Government and Consumer Services, 2017).

The BAO has no direct role in land use planning. Rather, they license the operators of a cemetery, who must satisfy the provincial Act and its regulations to operate a licensed 
cemetery in Ontario. Within this process, under the FBCSA, the applicant of an operating license must obtain municipal approval, at which time the public is notified of the decision and given fifteen days to appeal this decision to the Local Planning Appeal Tribunal. In the case that there are no appeals, the application is taken to the BAO, where a Registrar must review the proposed site plan, by-laws, and price list, considering factors such as consumer protection and whether the application is in keeping with legislation. If the Registrar issues a certificate of consent to the Land Registry Office, the land is then titled as cemetery land and is regulated under restrictions laid out in the FBCSA (Bereavement Authority of Ontario, 2019).

\subsection{Considerations and Challenges}

The following section will be a discussion of the key barriers that currently exist within the cemetery planning process. A broad review of existing literature on cemetery planning reveals a number of significant challenges within the cemetery planning process,

including: the diminishing amount of burial space, the lack of guidelines for cemetery planning in most cities, the lack of recognition of cemeteries as a land use, both in policy as well as amongst planners and at the municipal level, and a lack of research on alternatives to traditional full casket burials. Each of these has implications for the planning process as well as the integration of cemeteries into our urban landscape.

\subsubsection{Land Constraints \& Environmental Sustainability}

Cemeteries differ from most other land uses in two major ways: first, given the nature of their intended use, cemeteries are planned in perpetuity. Secondly, when a cemetery plot is purchased, the consumer is not buying the land itself; rather they are 
buying the right to occupy the space without being disturbed ${ }^{4}$. This results in a land use that is difficult to relocate ${ }^{5}$, for physical as well as cultural reasons, effectively locking that land out of other uses.

The process behind the creation of new cemeteries is lengthy and costly. Municipalities are hesitant towards this land use for a number of reasons. First, the lack of political will can be attributed to the discomfort around discussing death. Because of this, there are few advocates for cemeteries at the municipal level and amongst the public $^{6}$ (see Section 2.3.2). Secondly, cemeteries, as a business, do not generate a significant amount of income, yield a slow return on investment, and rarely break even. As a result, the rezoning process for a cemetery can take up to five or more years for approval and facilities may not open until years after the land is purchased. In the period between 1999 and 2004, only 84 acres of available burial space were added to two cemeteries in the Greater Toronto Area (Belford, 2018). Furthermore, municipalities and developers often see cemeteries as using up land that could otherwise be developed. Coupled with inconsistent zoning and rising development costs, cemeteries are increasingly being located on land that is not ideal or appropriate for interment.

In addition to occupying wide expanses of land, casket burials involve toxic chemicals in the embalming process and harmful materials going into the earth

\footnotetext{
${ }^{4}$ Personal communication (10 January 2019). Telephone interview.

${ }^{5}$ Cemetery closures are a long and drawn out process that require public input as well as input from groups such as the Ontario Historical Society, the Ontario Genealogical Society, the Ontario Archaeological Society, etc. Cemetery closure orders dictate that bodies must be disinterred and reinterred in an existing licensed cemetery. Ultimately, cemeteries can only be closed if it is in the public interest. In Ontario, there have only been three cemetery closures in the last 25 years (Bereavement Authority of Ontario, 2019).

${ }^{6}$ Personal communication (8 February 2019). Telephone interview.
} 
(Basmajian \& Coutts, 2010). The embalming process includes formaldehyde, phenol, methanol, and glycerin pumped into the veins of the body, which, when the body decomposes, leaches into groundwater (Calderone, 2015; Blakemore, 2016; Plenke, 2016). The caskets and liners themselves, usually made of plastic, metal or concrete, uses up tonnes of resources each year for the sole purpose of being buried (Calderone, 2015).

\subsubsection{Social Equity}

Death in Toronto has become an equity issue. The reluctance to develop new cemeteries, along with the increasing costs of plots in existing cemeteries, has resulted in an affordability issue not unlike Toronto's housing crisis. While being located near historical cemeteries can raise land values, most people tend to be resistant toward the possibility of cemeteries in their neighbourhood (Basmajian \& Coutts, 2010; Bennet \& Davies, 2015; personal communication, 2019). This NIMBYism (attitudes of Not In My Back Yard) pushes cemeteries out to the suburbs, where land values are on the rise. Some rural towns are experiencing an influx of non-resident consumers buying plots in their local cemeteries for the lower cost, leading cemetery organizations to restrict lot sales to residents or descendants of residents (Capels \& Senville, 2006). Like housing for the living, access to space is a matter of who can afford the land.

Planning for an increasingly diverse city such as Toronto includes challenges and considerations that planners should have regard to; planning cemeteries is no different. Many religions have strict regulations and rituals surrounding death as well as requirements for interment that cannot be disregarded for the intentions of saving space. The following table summarizes the burial practices permitted in each major religion. 
Table 2. Interment Methods Permitted by Major Religions ${ }^{7}$

\begin{tabular}{|c|c|c|c|c|c|c|}
\hline $\begin{array}{l}\text { Interment } \\
\text { Method }\end{array}$ & 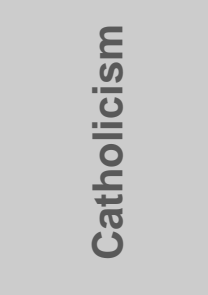 & 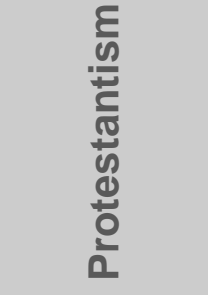 & $\begin{array}{l}\frac{\varepsilon}{0} \\
\frac{0}{\pi} \\
\frac{0}{0} \\
\frac{0}{\rho}\end{array}$ & $\frac{E}{\frac{E}{0}}$ & $\begin{array}{l}\frac{E}{0} \\
\frac{0}{3} \\
\overline{0} \\
\frac{\bar{I}}{1}\end{array}$ & 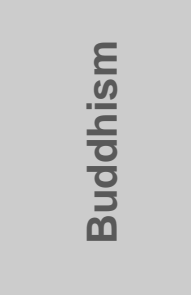 \\
\hline $\begin{array}{l}\text { Casket } \\
\text { Burial }\end{array}$ & Permitted & Permitted & Permitted & Permitted ${ }^{8}$ & Permitted & Permitted \\
\hline Cremation & Permitted & Permitted & $\begin{array}{c}\text { Not } \\
\text { permitted }\end{array}$ & $\begin{array}{c}\text { Not } \\
\text { permitted }\end{array}$ & Permitted & Permitted \\
\hline $\begin{array}{l}\text { Scattering/ } \\
\text { keeping } \\
\text { ashes }\end{array}$ & $\begin{array}{c}\text { Not } \\
\text { permitted }\end{array}$ & Permitted & $\begin{array}{c}\text { Not } \\
\text { permitted }\end{array}$ & $\begin{array}{c}\text { Not } \\
\text { permitted }\end{array}$ & Permitted & $\begin{array}{c}\text { Not } \\
\text { permitted }\end{array}$ \\
\hline $\begin{array}{l}\text { Green } \\
\text { Burial }\end{array}$ & Permitted & Permitted & Permitted & Permitted & Unknown & Permitted \\
\hline $\begin{array}{c}\text { Double } \\
\text { depth } \\
\text { burial }\end{array}$ & Permitted & Permitted & Unknown & Permitted & Permitted & Permitted \\
\hline
\end{tabular}

\subsubsection{Lack of a Planning Framework}

Cemeteries must be recognized as a key land use concern, with social, cultural, environmental, and economic implications. However, most municipalities do not have the will to conduct cemetery planning frameworks or guidelines. As discussed above, few policies recognize the importance of cemeteries for a complete community and most

${ }^{7}$ Source: Developed from Hariyono, 2015.

8 Though casket burials are permitted, the burial practices mandated in Islam are in line with what is referred to in this paper as a green burial: the interment of an unembalmed body in a shroud and no container, and either modest markers or no marker. 
planners and municipalities simply do not think about or plan for death in the same capacity as they plan for other uses.

Creating a framework for the planning of cemeteries is further complicated by the lack of publicly accessible data (Coutts, Basmajian, \& Chapin, 2011). As a result, planners often must rely on data from cemetery owners, which may be incomplete (Basmajian \& Coutts, 2010). Projecting future needs of cemeteries becomes even more difficult when considering the multitude of factors that impact one's choices for interment. Coutts et al. (2011) developed a methodology that can predict future demand for cemetery space using statistics on mortality rates, cremation rates, and land capacity. However, this data cannot account for patterns such as burial migration or trends such as alternatives to full casket burials.

Civic engagement in the cemetery planning process has been explored by several scholars, discussing public pushback to specific site proposals as well as contentious methods of interment such as grave reuse (Basmajian \& Coutts, 2010; Bennett \& Davies, 2015; Bennett \& Davies, 2016). Some planners highlight the need for more a more open public consultation and involvement process to help curb NIMBY attitudes with regards to cemeteries and stress the importance of designing for the integration of cemeteries within the community, as a few cities have done (Basmajian and Coutts, 2010). Any framework for the planning of cemeteries should also include strategies for public engagement and education to further attempts at dispelling any negative attitudes.

Lastly, and most salient to this discussion, there has not been adequate research conducted on the potential benefits and implications of alternative interment measures. In addition to not being recognized by zoning by-laws and land use policies, the effects 
that alternatives to full casket burials can have on ecology, affordability, and land have not been fully explored. While practices such as cremation, green burials, and grave reuse are gaining popularity internationally and require less land than casket burials, they still face resistance for a variety of reasons (Basmajian \& Coutts, 2010; Coutts, Basmajian \& Chapin, 2011; Kong, 2012; Lehrer, 1974). These are explored in the following chapter. 


\subsection{Case Study}

\subsection{Vertical Cemeteries: Cremation and Columbaria}

The popularity of cremation is on the rise in North America, parts of Europe, and, more recently, urban centres in Asia (Hariyono, 2015) due in part to the process being more ecologically sustainable than traditional burial, as this process requires less land and eschews chemicals that are used in the embalming process (Basmajian \& Coutts, 2010 , p. 306). The proliferation of cremation can also be contributed to its acceptance by most of the world's major religions: cremation is accepted in Catholicism, Protestantism, Hinduism, and Buddhism (Hariyono, 2015, p. 204) [see Table 2].

Cremation accounted for $52 \%$ and $71 \%$ of interments in the United States and Canada respectively in 2017 (Cremation Association of North America, 2018). However, it is important to note that the trend is also shifting from columbaria to in-ground burials of cremated remains (de Sousa, 2015; Belford, 2018). As such, there is still a significant amount of space that must be allotted for this method of interment, albeit less than the traditional burial. The interment of cremated remains demands a plot of $0.6 \mathrm{~m}$ by $0.79 \mathrm{~m}$ $\left(0.47 \mathrm{~m}^{2}\right)$, less than one-sixth of the land required for a traditional casket burial, which measures roughly $1.0 \mathrm{~m}$ by $2.7 \mathrm{~m}\left(2.7 \mathrm{~m}^{2}\right)$ (Belford, 2018). In some cases, the ashes are deposited into an urn and given to the family or scattered in scattering grounds or into the sea (Kong 2012; Hariyono, 2015). While capital funds have been used to build crematoria, more funding and research on cremation is required for the proper investment into and planning of cemeteries (City of Hamilton, 2015). To combat this, some countries have begun to implement vertical cemeteries: these high-rises for the dead, adopted in Israel, 
Japan, and Brazil, have been designed to house cremains (or caskets in Israel where the dominant religion does not permit cremation) without sacrificing respect, dignity, or religion in the pursuit of saving space (de Sousa, 2015; Gorvett, 2017; Elliott, 2018).

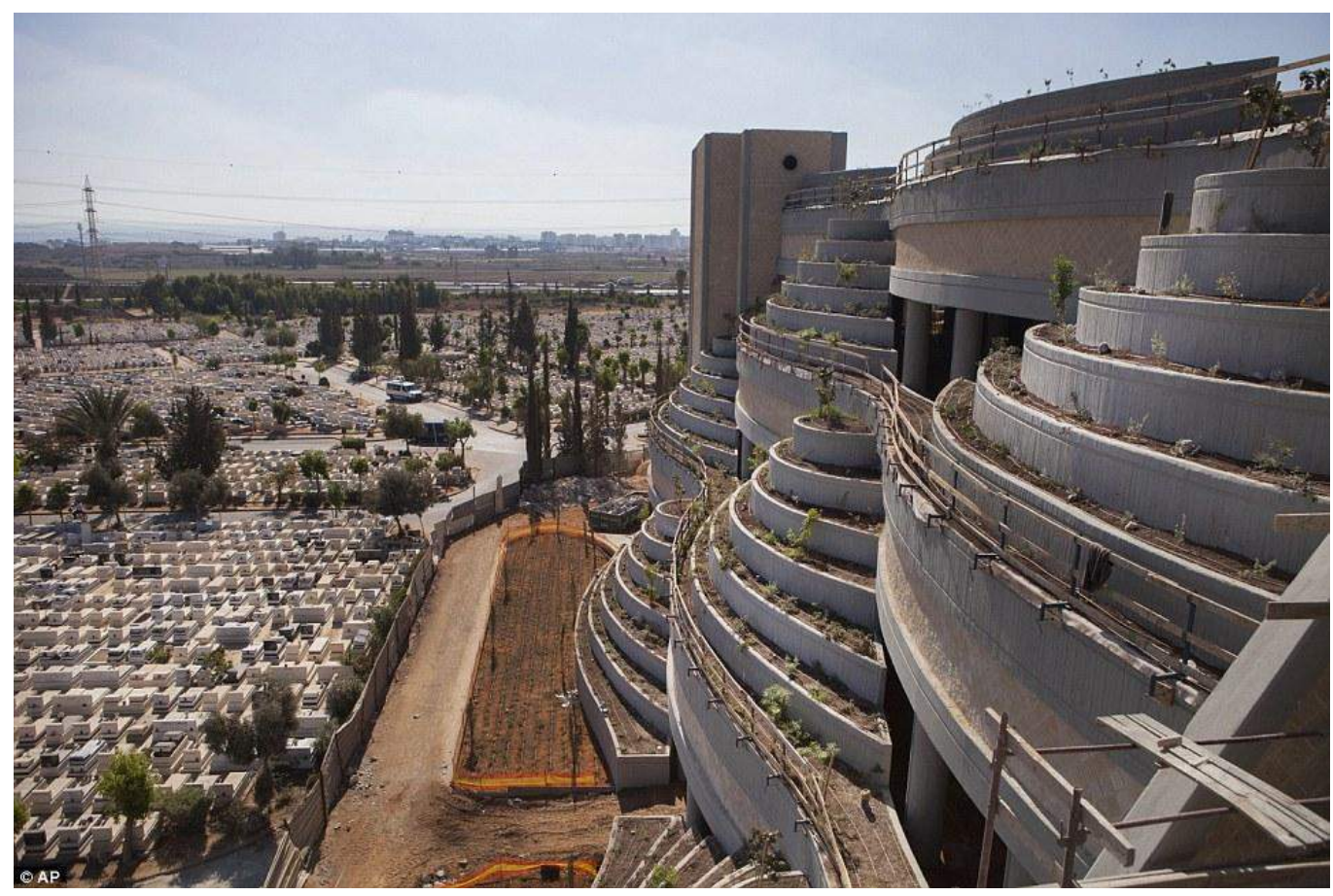

A vertical interment facility at Yarkon Cemetery in Tel Aviv, Israel.

\subsubsection{Hong Kong}

In the past few decades, Hong Kong has experienced a dramatic growth in population, from 650,000 in 1945, to 2 million in 1950, to 5 million in 1980 (Teather, 1999, p. 413), reaching a population of over 7 million by the end of 2018 in a land area of just 1100 square kilometres (Census and Statistics Department, Government of the Hong Kong SAR, 2019). Hong Kong's burial grounds are the site of continued tension between values of traditional culture and modernity. Amongst the Hong Kong Chinese, paying respects to the dead on birthdays, anniversaries, and Gravesweeping Festivals such as 
the Ching Ming Festival is an important tradition that must be upheld (Teather, 1998; Kong, 2012). On these days, families gather at the graves of ancestors, clearing weeds, lighting candles, burning incense, and sharing food. Yet deathscapes are seen as unclean in Chinese culture and thus are often avoided except on significant dates (Kong, 2012). The result is large expanses of land that are rarely frequented and decrease property values of adjacent properties (Teather, 1998).

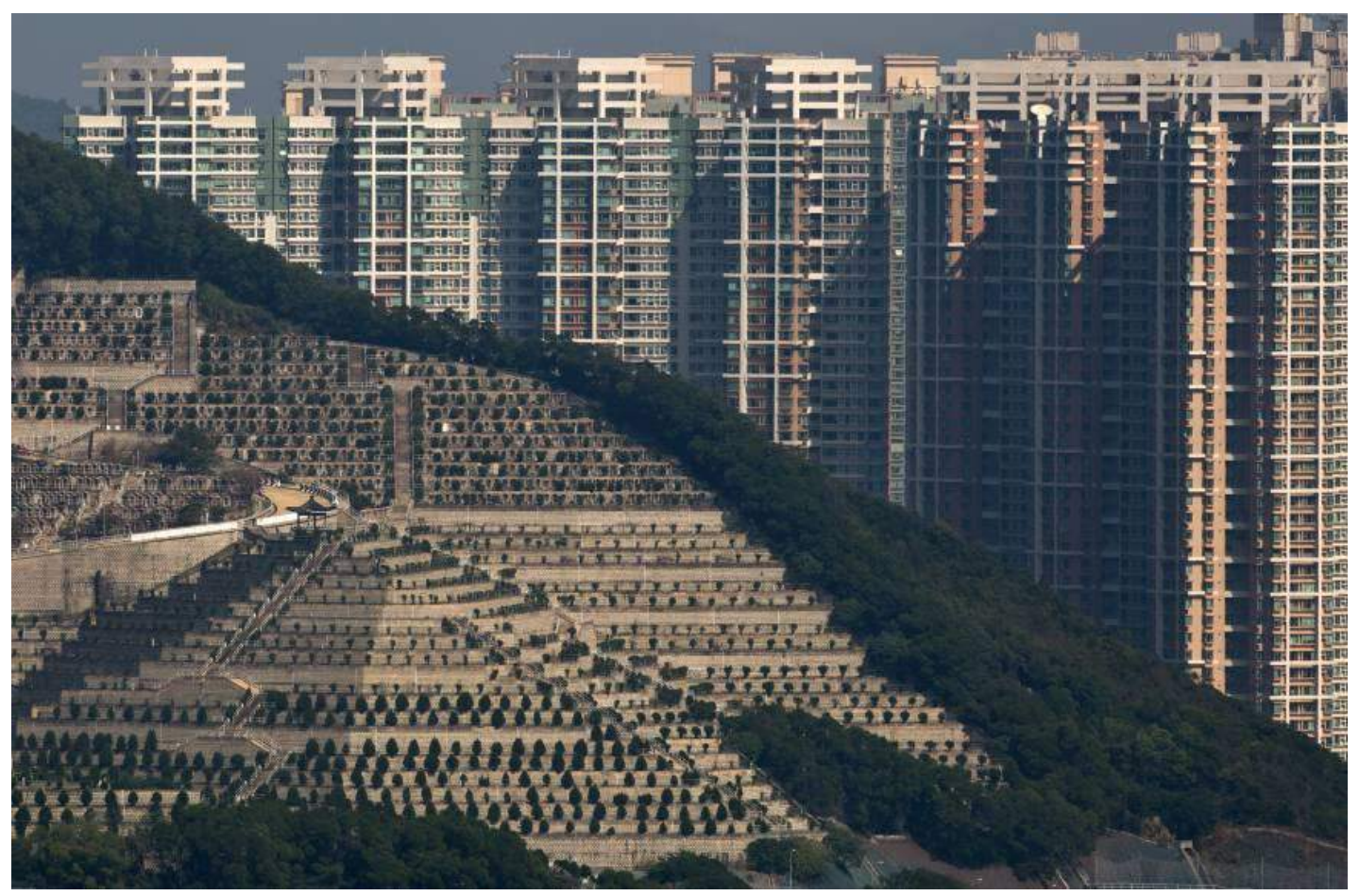

Land-density amongst the living and dead in Hong Kong. 
Beginning in 1950, the Hong Kong government ceased provision of municipallyrun cemeteries and instead established public columbaria and crematoria, including a crematorium for every town with a population of over 350,000 (Teather, 1999, p. 414). In 1968, the government set out to encourage cremation by creating new crematoria and columbaria and raising the costs of grave burials in order to accommodate the rising population amidst land scarcity (Kong, 2012). New polices were also introduced that returned the land back to the government after a period of six to seven years, at which time the grave would be exhumed and the body cremated and stored into urns (Teather, 1998). Despite the government's efforts, many Hong Kong residents still prefer burial to cremation for cultural and societal reasons, though for most, this is not financially feasible (Teather, 1999).

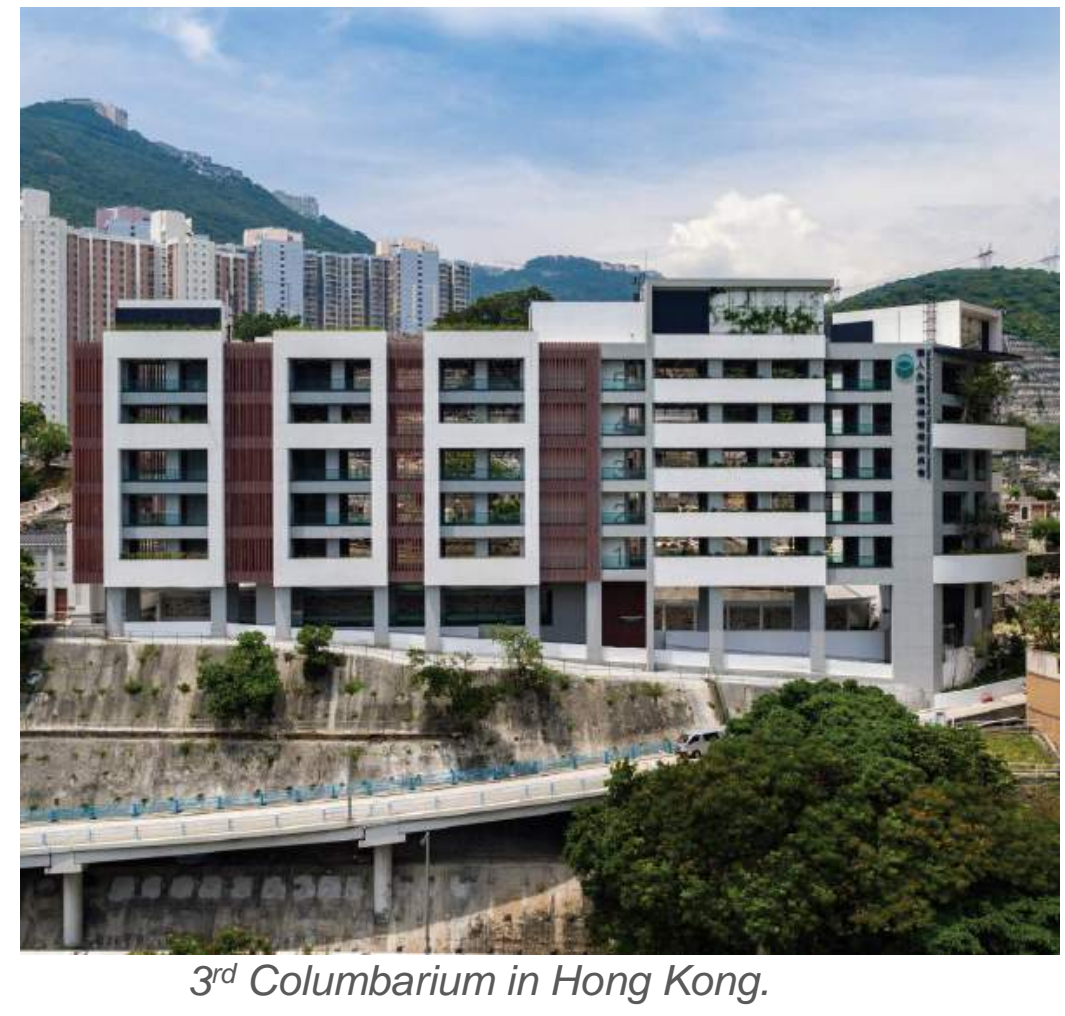


Architects were challenged with designing culturally sensitive yet functional columbaria: these buildings had to be well-lit, spacious enough for visitors, and easily cleaned and maintained from the operator's perspective. The surrounding area outside the columbaria were decorated with statues, obelisks, and auspicious symbols, and, where possible, landscaped with trees (Teather 1998; Teather, 1999).

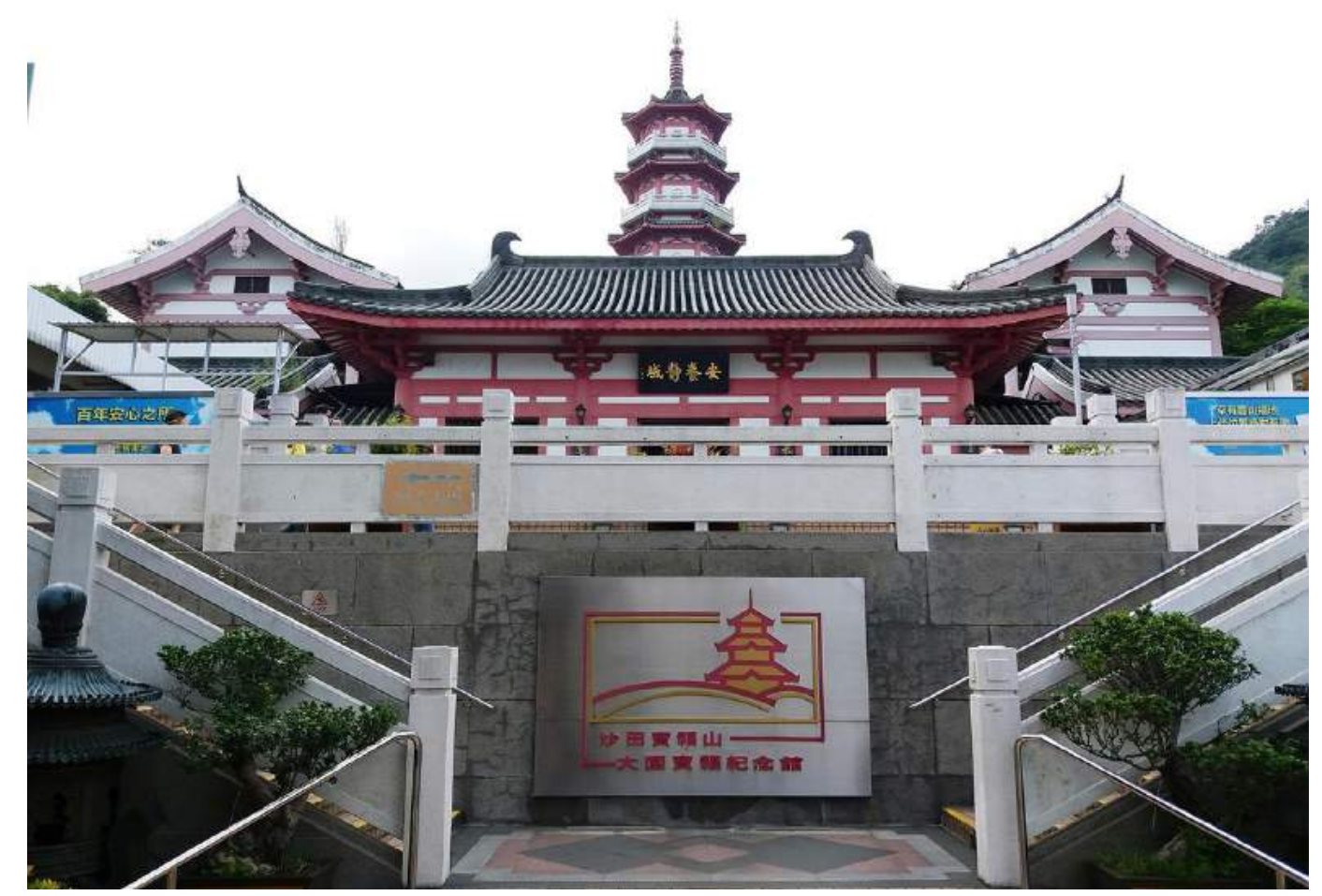

Columbarium at Po Fook Hill in Hong Kong, featuring a pagoda-style roof.

Hong Kong's cremation rate rose from $35 \%$ in the decade after the campaign was introduced to 68\% in 1993 (Teather, 1998, p. 25) to 90\% in 2013 (Blundy, 2017). The wealthiest of Hong Kongers can afford to choose full casket burials in family grave sites, which remains the ideal in Chinese culture, but for the vast majority of residents, columbaria have proven to be an affordable and culturally acceptable option for interment. 


\subsubsection{New Delhi}

The practice of cremation has always been the cultural norm in India, with a majority Hindu population of $82 \%$ (see Table 1). Similar to Hong Kong, where the government imposed policies to encourage cremation over burial as a means of saving space, the Delhi government has begun to promote alternative methods of cremation for environmental, economic, and social reasons (Singh \& Manohar, 2018). Given the high population density, New Delhi is predicted to run out of burial grounds for the city's Muslim community (about $13 \%$ of the population) by 2020 . Transporting bodies outside of Delhi, where there are newer cemeteries that still have vacancies, is an expensive process that not many can afford (Joshi, 2018).

In addition to the land crisis, the government's policies are also motivated by ecological reasons. Hindu cremation rituals are performed on a wood pyre rather than a cremation unit. With almost 80,000 wood-based cremations taking place annually in the province, each requiring around $500 \mathrm{~kg}$ of wood, it was estimated in 2016 that $4 \%$ of carbon monoxide emissions daily was attributed to cremation sites (Singh \& Manohar, 2018). Fifty to sixty million trees are burned for cremations annually in India, resulting in about 8 million tonnes of carbon dioxide and other greenhouse gas emissions (Singh, 2015).

To address these issues, the government has introduced new technologies such as electric and compressed natural gas crematoria. Though these units are less expensive, less time consuming, and more sustainable than traditional wood cremations, people were unwilling to try the new method for religious reasons. Currently, Delhi only has two electric and six compressed natural gas units, though a small proportion opt for 
these alternatives (Singh \& Manohar, 2018). Cemeteries in Delhi have ceased to allow permanent graves, with one Christian cemetery optimizing land through the installation of a vertical cemetery: completed in 2015 and the largest of its kind in Asia, officials of the St. Thomas Christian Cemetery constructed a 'vault' with 300 cells on two walls surrounding a 15 metre pit. Bodies are interred in these cells until they decompose, at which point they are pushed into the pit to return to the earth. The vault is predicted to become full after 4-5 years and the cells can then be reused (Joshi, 2018).

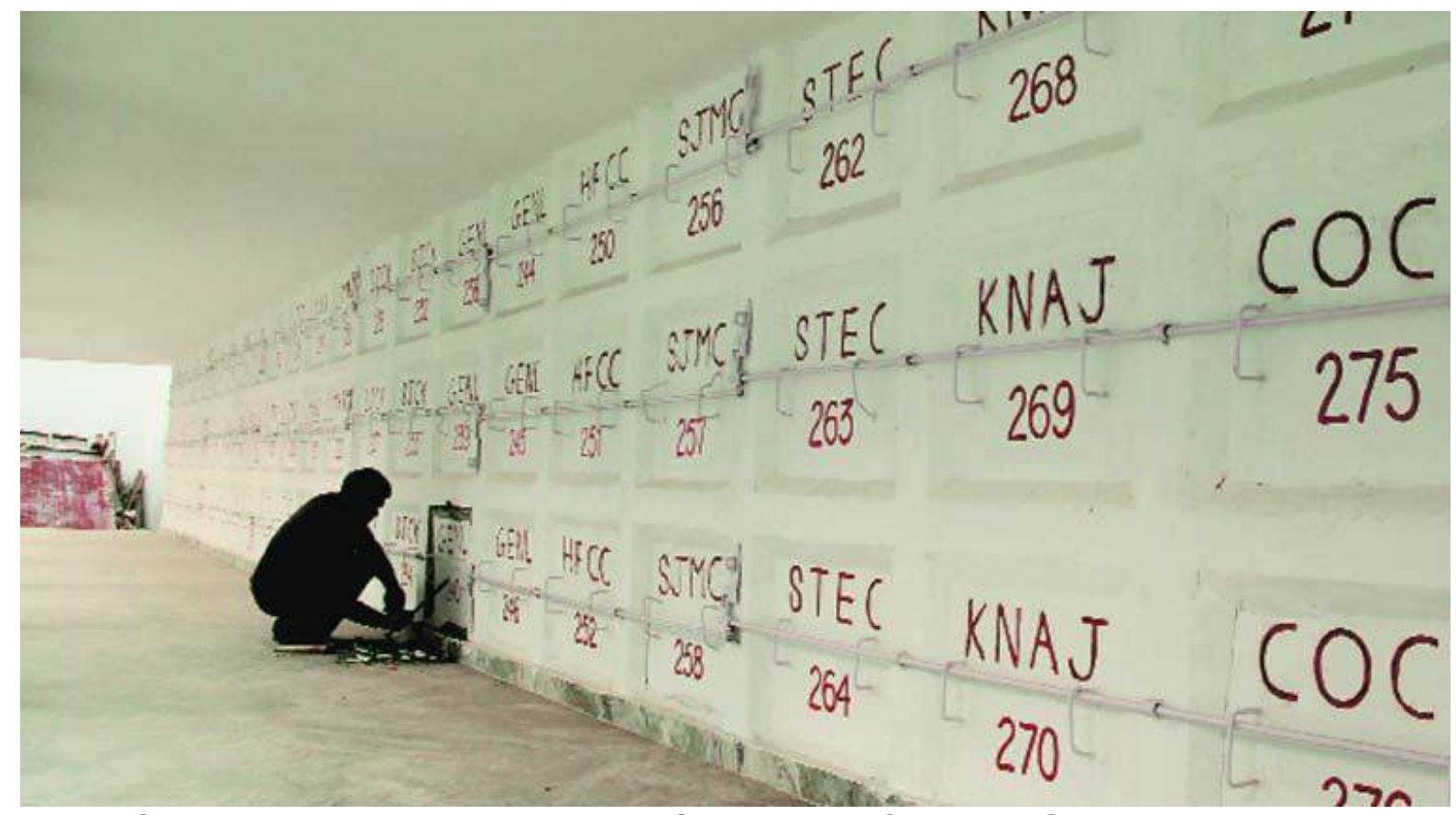

Cells at the vertical cemetery in St. Thomas Christian Cemetery in Delhi.

Both the new cremation units and the vertical cemetery are more cost efficient and more sustainable than traditional wood-based cremations. However, unlike Hong Kong, the efforts by the government to encourage alternative methods have not been as well received. Delhi provides some lessons to be learned from the introduction of this 'gentle verticalism', though the programs to encourage alternative forms of cremation lack the 
same regard that the Hong Kong architects tasked with designing the columbaria held for culture and religion. The vertical cemeteries, as a form of green burial, (discussed in the following section) can accommodate the Indian Muslim population, but for the vast majority of Delhi and India as a whole, the benefits of electric cremation units are simply not enough to sway the Hindu population from following the tenets of their faith. As one supervisor at a Delhi crematorium states, "When someone has lost a relative, environment is the last thing on his mind" (Singh \& Manohar, 2018).

\subsection{Green Burials and Landscaped Cemeteries}

Outside of the traditional casket burial and cremation, people are more often looking toward green burial as their preferred method of interment. In a green burial, caskets, grave liners, protective vaults, and embalming are eschewed and the body is wrapped in a biodegradable fibre shroud and placed directly in the grave or in a biodegradable container. The surface of the grave is then marked with a stone, tree, or local plant that visitors can use to identify the grave (Green Burial Society of Canada, 2015). Some families will opt for above ground memorialization such as a plaque on a wall and GPS coordinates that allow them to find the site for later visitations ${ }^{9}$. Rather than the traditional grave markers that characterize lawn cemeteries, the emphasis is on nature as a communal memorial rather than on the preservation of individual identities (GBSC, 2015; Clayden et al., 2018, p. 99). Green burials also perform valuable

9 Personal communication (10 January 2019). Telephone interview. 
ecosystem services by increasing green cover, regulating air and water quality, improving permeability, and enriching the larger urban area (Clayden et al., 2018).

Outside of its environmental benefits, green burials are culturally sensitive and gaining wider acceptance in North America; natural burials are in line with Jewish and Muslim burial practices, which abstain from the use of embalming chemicals and use simple caskets in lieu of metal caskets or vaults (GBSC, 2015). Green burial plots are less expensive to maintain, at around $60 \%$ of the operations cost of a traditional casket burial and grave marker ${ }^{10}$. The plot of land costs the same as a traditional burial, but individuals save money by opting for a simpler casket (or none at all) and rejecting embalming and headstones. While the price of a typical traditional funeral and burial in North America will range from $\$ 8000$ to $\$ 10,000$, a green burial costs half of that (Ponciano, 2018), making this option more accessible for lower-income households.

In tandem with green burials, cemeteries are increasingly being designed to be more accessible and inviting, a callback to the cemetery as the first urban park. A study in Norway found that Scandinavian cemeteries are often used outside of their primary purpose, for quiet activities such as dog walking, biking, crossing, or exploration (Evansen et al., 2017). Passive recreation is facilitated in cemeteries through features such as paths, seating, trees that enclose the cemetery from the surrounding area, and lowered hedges and fences to create a more welcoming entrance. Some cemeteries even operate

10 Personal communication (10 January 2019). Telephone interview. 
as a type of open-air museum, offering guided tours and interpretation centres on site (Babic \& Bingula, 2015).

\subsubsection{Berlin}

A number of strategies were adopted when burial lands started to become scarce in Berlin. Cemetery officials began to lease their plots, while others opted for cremation (Chase, 2015; McMillan, 2016). Unlike Hong Kong or New Delhi, however, cemeteries in Berlin have not implemented dedicated infrastructure for storing cremains. German burial laws also dictate that families are prohibited from taking home the ashes of their loved ones: ashes must be buried in cemeteries or designated areas, which include forests, fruit orchards, or the sea (Paul, 2017). "Family trees" are a popular choice for interment. Cremated remains are buried in biodegradable urns (or wicker caskets, pods made of recycled paper, and biodegradable shrouds (Walker, 2016)) at the base of a tree selected and purchased by the client's family, who, at the time of need, will also be buried at the same tree (McMillan, 2016; Paul, 2017). Individuals are memorialized with a name plaque attached to the tree, personal mementos such as ribbons tied around trees, and native species of flowers (Krause, 2015; McMillan, 2016). The cost of a forest burial in Berlin is around 770 euros (840 CAD), while a family tree (which houses up to 10 plots) can cost upwards of 3350 euros (5000 CAD) depending on the location and type of tree. This is still far more affordable than a single casket burial at almost half the cost (Krause, 2015).

The first "forest cemeteries" emerged in Germany in the early 2000s, and since then, more than 60 have been established across the country (Walker, 2016). With the proliferation of forest burials, the German Cemetery Association predicts that "a third of the cemeteries in Germany won't continue to exist in their present from five to ten years 
from now" (Paul, 2017). When the demand for cemeteries decreased, some cemeteries were converted into public parks or playgrounds (McMillan, 2016). Now, urban planners in Berlin realize that people have come to see cemeteries as public parks: a 2014 study conducted in Berlin found that people walk, read, and sunbathe in cemeteries, as they provide quieter alternatives to busy public parks. Unsurprisingly, recreational activities were more common in cemeteries situated in or near residential neighbourhoods (Paul, 2017).

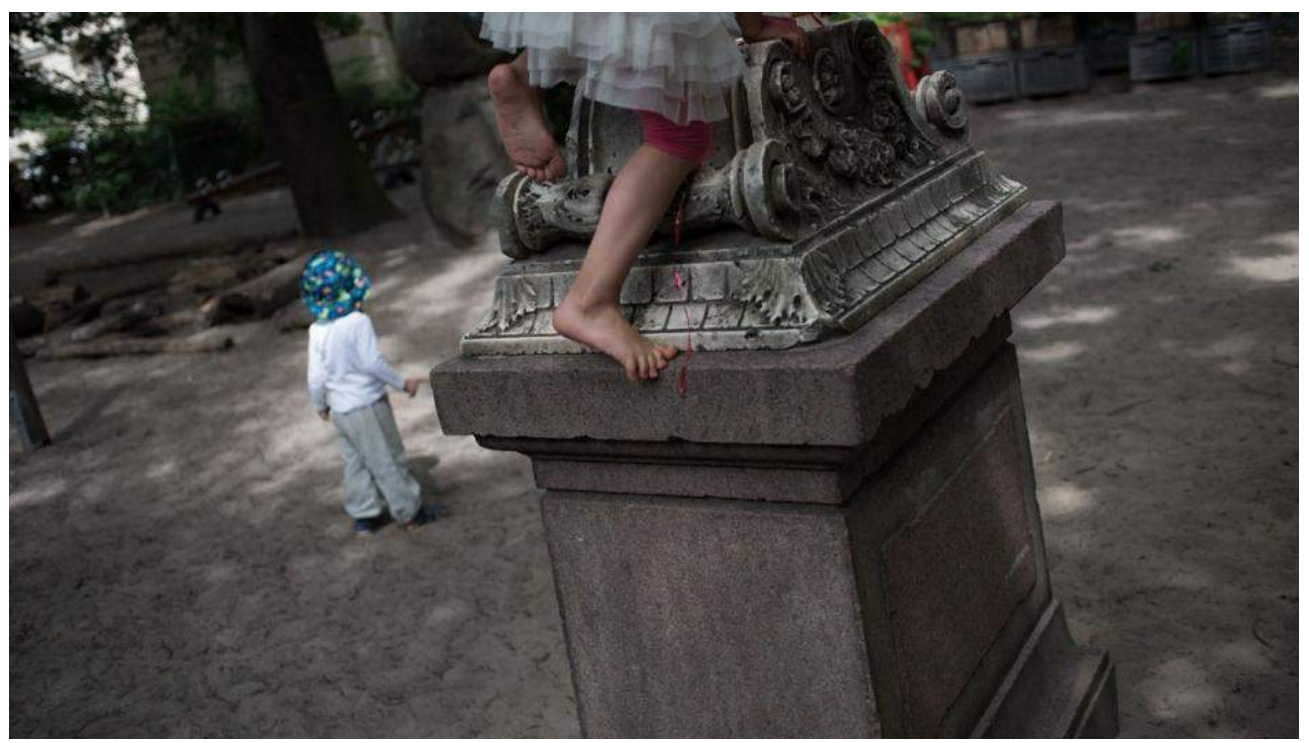

A child climbs atop a headstone in a cemetery-turned-playground at a daycare centre.

\subsubsection{Taipei}

As in Berlin, cemetery officials in Taipei implemented lease burial policies and began to encourage cremation in columbaria (Kong, 2012). However, with Taiwan's cremation rates exceeding that of grave burials, and columbaria in many major cemeteries reaching capacity (Kong, 2012; Steger, 2019), the residents of Taipei, Taiwan's densest city, have sought other space-efficient means of honouring their dead. Scattering is one alternative that has been encouraged by the Taipei government, with 
an emphasis on environmental benefits (Kong, 2012; Liu \& Liu, 2018). Columbaria niches are also rented on a lease basis and exhumed after 50 years unless renewed, at which time the ashes are reinterred, either through burial or scattering. The Taipei government has had its hand in promoting green burials through subsidies for people who want to exhume the ashes of their relatives from columbaria into a green burial site (Steger, 2019). In 2018, the Taiwanese Ministry of Interior announced that due to the consistent decline in burial rates, solar panels would be installed in cemetery lands, in the country's efforts to become nuclear-free within the next decade (Everington, 2018).

Culturally, the practice has increasingly become accepted, as it is an affordable means of keeping the family together and seen as a return to nature (Kong, 2012). Though Taiwanese culture idealizes an eternal resting place for the dead, more than $20 \%$ of citizens in Taipei (compared to only 13\% in Hong Kong) opted for natural burials in 2018, particularly tree burials (Steger, 2019). New trees planted in honour of the dead symbolize a renewal that bereaved families find comforting (Kong, 2012). However, Taipei's green burial practices are not without their environmental shortcomings. During the Ching Ming Festival, graves are littered with decorations, religious figurines, and plastic toys that families leave as grave markers. This led to a ban in 2007 on all personal effects, instead marking graves with a rock or by planting a tree (Kong, 2012).

Since 1976, the Taiwan government has undertaken programs and projects to "beautify" cemeteries and change the perception that the Taiwanese people hold regarding cemeteries (Huang, 2007). The goal of the Public Cemetery Improvement Project was to redesign public cemeteries to create a park-like experience to enhance the environment and provide clean, attractive spaces for visitation, worship, and leisure 
(Huang, 2007, p. 208). Through this project, 216 public cemeteries were subsidized through the government to be landscaped according to the following principles: leveled grave mound design; unified plot size; lease burial; gardening; amenities such as washrooms; and introduction of crematoria (Huang, 2007). Upon evaluation of the success of this project, it was found that in addition to funeral rites and visitations, uses of cemeteries had expanded to include activities such as studying, painting, jogging, and practicing Tai Chi (Huang, 2007, p. 212). Presently, there are two public parks that double as natural burial sites in Taipei: these parks even hold concerts at tree-burial grounds as a commemoration of lost loved ones (Liu \& Liu, 2018; Steger, 2019). Despite the overall success of this project, the idea of recreation mixed with one's final resting place is unsettling in traditional Chinese culture; of the activities that take place in cemeteries, people are more receptive to quieter, more passive activities such as reading or strolling (Huang, 2007, p. 219).

Taipei and Berlin, through different means, have created deathscapes wherein cemeteries function as public parks that commemorate the dead through respectful shared use of the space. Taipei required more active interventions through subsidies, policies and programs, leading to an eventual cultural restructuring to permit this type of use. In Berlin, though there was less government intervention, change was facilitated by a recognition on the part of city planners of cemeteries as a crucial and overlooked land use that can bring about social and environmental benefits. 


\subsection{Grave Exhumation and Reuse}

Thus far, each city in the case study has been shown to adopt cremation in some form, either stored in columbaria, scattered, or buried in forests or parks. However, for some, cremation is not an option, whether that be for cultural or religious reasons, or simply personal preference. In these instances, double-depth burial provides a more affordable and land-efficient option for a casket burial. Grave reuse has been practiced in cemeteries throughout Europe since the $18^{\text {th }}$ century, yet is the subject of contention in many countries, particularly the west, as people oppose to the disturbance of graves (Rugg 2013). Graves can be exhumed prior to the closing of a cemetery or for freeing up the land for development, as has been done in Singapore (Han, 2015; Au-Yong, 2017; Chandran, 2019). This section will discuss cities which employ the 'lift and deepen' method of grave reuse, where the existing body is exhumed so the grave can be deepened. The body is then reinterred, and the new body buried on top, with at least six inches of dirt between them and at least two feet between the new interment and the surface (Rugg, 2013, p. 4). Despite common misconceptions, this process is conducted as gently as possible and without disturbance, as the body is not removed from the gravesite (Rugg, 2013, p. 6). Graves marked for reuse must be at least 75 years old, such that the remains have decomposed (Rugg, 2013; Carrington, 2016). Notice is then given to the family, either in newspapers or a posting on the headstone, giving relatives a window of six months to object to the grave's reuse (Carrington, 2016). 


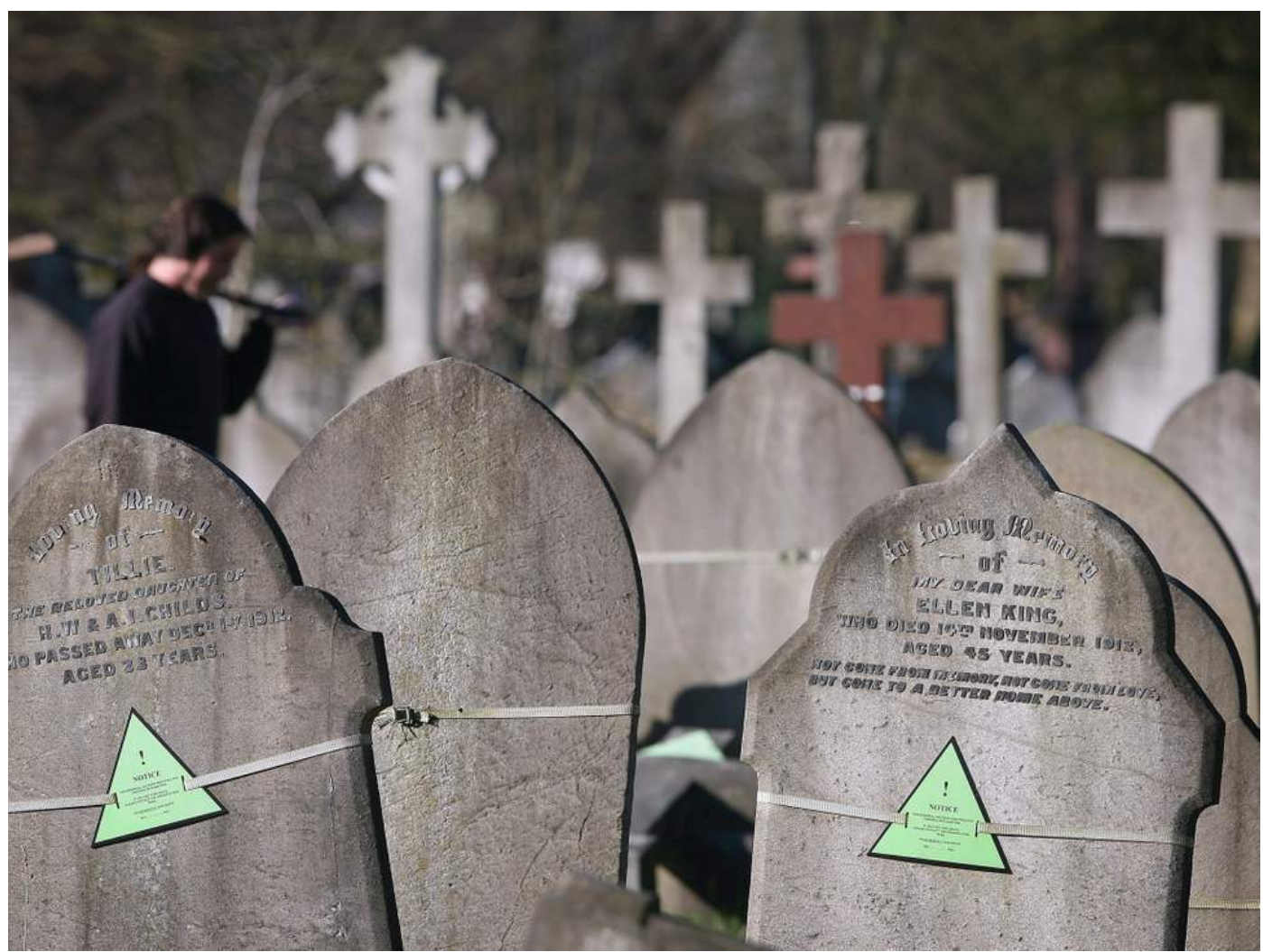

Graves in London marked with a notice of reclamation.

Grave reuse is uncommon in North America, but in cemeteries that allow this practice, people appreciate the method for its environmental and financial benefits. Deepening graves allows cemeteries to grow "downwards" rather than outwards, creating the opportunity for more burials without occupying more space. In one Vancouver cemetery, a new grave can cost $\$ 27500^{11}$, while the cost of opening a grave and the burial costs $\$ 1715$ (Mclntyre, 2017). The idea of being able to be buried with one's ancestors on the same plot is also comforting, especially when the scarcity of land causes families to be separated (McManus, 2015; Mclntyre, 2017).

11 Personal communication (3 April 2019). Email communication. 
Under the FBCSA (2002), grave reuse is prohibited in Ontario, though double depth burials are permitted, subject to the cemetery owner or registrar and in keeping with by-laws and the public interest. Cremated remains, which have no restriction on the depth at which they must be buried, can be buried above a casket interment. In practice, this becomes complicated once the interment rights have been exercised, such as in cases where a set of cremated remains is interred in an unoccupied grave that then needs to be disturbed and opened for a casket burial ${ }^{12}$.

\subsubsection{London}

Despite the United Kingdom's high cremation rates, which exceeded burial rates in the 1960s (Rugg, 2013), half of the municipal cemeteries in England are predicted to run out of space within the next two decades, according to a 2013 survey (McManus, 2015; Carrington, 2016). Grave reuse, which is permitted under Church law, has long been practiced in churchyards (Rugg, 2013); yet the City of London cemetery is the only cemetery in the UK that permits the lift and deepen method, and has been doing so since 2007 (Carrington, 2016; Cohen, 2019). In addition to the lack of land, cuts to municipal budgets have contributed to the rising costs of burials: the average cost of a casket burial in London has increased to almost $£ 4,800$ (8500 CAD) in 2018, an increase of $70 \%$ within a span of ten years (Cohen, 2019). Today, more than $60 \%$ of burials in the City of London Cemetery are in reused graves, which the cemetery operators attribute to the cheaper cost, both for the clients as well as from a management standpoint (Bawden, 2014).

\footnotetext{
12 Personal communication (3 April 2019). Email communication.
} 
While grave reuse as a practice is not illegal, most municipal and private cemeteries do not allow reuse (Bawden, 2014; Cohen, 2019). In order for more municipal cemeteries to follow in the example of the City of London Cemetery, legislation must be passed, yet the lack of political action discourages other cemetery operators from pursuing this avenue (Rugg, 2013; Cohen, 2019).

\subsubsection{Singapore}

In land-starved Singapore, with a size of 719 square kilometres and an entirely urban population, tensions for land have long existed between the living and the dead. In 1978, burial grounds made up less than $5 \%$ of land (Han, 2015), yet cemeteries have long been regarded as a 'waste of space' (Teo et al., 2004, p. 197). In 1988, like many East Asian urban centres, the government of Singapore introduced a lease-burial system, setting a 15-year limit on burials, after which remains are disinterred in smaller plots or cremated (Teo et al., 2004; CBC, 2005; Chandran, 2019). Despite this policy, Singapore continued to run out of developable land, and turned to exhuming cemeteries to free up land for the development of high-rise condominiums and hotels (Han, 2015; Chandran, 2019). The Singaporean government has been exhuming graves in the Bukit Brown cemetery with the intention of clearing 4000 graves for the installation of an eight-lane highway (Chandran, 2019). In another exhumation project that began in 2006, tens of thousands of graves are to be exhumed in Choa Chu Kang, the city state's only cemetery still open for operation, to clear space for the expansion of a nearby air base (CBC, 2005; Chandran, 2019). The Chinese graves in Choa Chu Kang are to be cremated, while the 35,000 Muslim graves are reinterred in deepened graves and placed into concrete crypts (Au-Yong, 2017; The Straits Times, 2017). 
In addition to paying for the reinterments, the government has taken efforts to make the exhumations as 'gentle' as possible (Teo et al., 2004). Like in London, any relatives are notified of and given the chance to object to the decision. For a Taoist or Buddhist family, a Feng Shui master or priest conducts the exhumation with the family present, using delicate tools so as not to disturb the remains, which are given to the National Environment Agency for cremation. For a Muslim grave, family members are also present for the exhumation and recite prayers as the gravedigger collects the remains. Remains are then wrapped in linen and cleaned, before being lowered into the new grave, a concrete crypt, which holds the remains of eight people in one grave. The eight names are engraved on a plaque for future visitations (The Straits Times, 2017).

In spite of the government's efforts, many Singaporeans rally for the preservation of Bukit Brown and Choa Chu Kang, citing their historical and cultural significance (Han, 2015; Chandran, 2019). Activist groups host walking tours of these spaces in the efforts of promoting these spaces for public use, especially as cremation rates continue to rise amongst Singapore's mostly Chinese population (Teo et al., 2004; Chandran, 2019). For the conservationists, this is also a social equity issue: in the past, large expanses of burial ground have been exhumed to make way for high end shopping districts, which are inherently exclusionary toward low-income individuals. Following in the success of cities like Berlin and Kuala Lumpur, they advocate for preservation and the conversion of these spaces into heritage parks that can be enjoyed by the public (Han, 2015; Chandran, 2019). 


\subsection{Discussion}

The cities discussed in this case study reveal patterns that should be considered for the planning of Toronto's cemeteries. Every city demonstrated varying degrees of government intervention intended to address the land-scarcity issue. Moreover, these policies or programs were designed with considerations toward environmental sustainability and cultural accommodations in mind, often successfully. In London, the lack of political will to amend the laws surrounding grave reuse prevents cemetery operators from being able to utilize this proven method of saving space. The involvement of urban planners in addressing these issues was also inadequate, with planners in Berlin as the exception (though their role was reactionary rather than proactive). Through the sensitive and careful design of columbaria and scattering gardens, Hong Kong and Taipei demonstrate that it is possible to invoke cultural change while respecting diverse cultural needs. A cultural shift is not always possible, as evidenced in New Delhi, but the introduction of new technologies in the funeral industry present more environmentally sustainable options for the future. 
Table 3. Interment Method Compatibility Matrix

\begin{tabular}{|c|c|c|c|c|c|c|c|}
\hline & \multicolumn{7}{|c|}{ Method } \\
\hline Considerations & 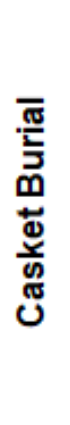 & 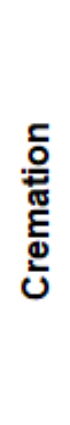 & 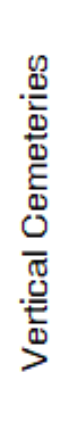 & 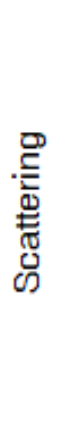 & 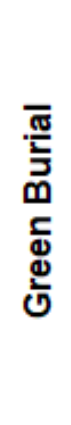 & 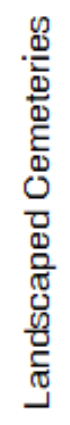 & 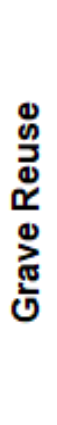 \\
\hline Land-efficiency & & & & & & & \\
\hline Environmental & & & & & & & \\
\hline Cultural/Religious & & & & & & & \\
\hline Protestantism & & & & & & & \\
\hline Catholicism & & & & & & & \\
\hline Islam & & & & & & & \\
\hline Judaism & & & & & & & \\
\hline Hinduism & & & & & & & \\
\hline Buddhism & & & & & & & \\
\hline Affordability & & & & & & & \\
\hline Maintenance & & & & & & & \\
\hline
\end{tabular}

\begin{tabular}{|l|l|}
\hline & Beneficial/permitted \\
\hline & Somewhat beneficial/no effect/unknown \\
\hline & Not beneficial/not permitted \\
\hline
\end{tabular}

The compatibility matrix above assesses each interment method for landefficiency, ecological sustainability, affordability, and religious acceptance, in comparison with full casket burials. Relative to casket burials, each method explored proved to be 
more affordable while occupying less space. The key differences were revealed in the level of sustainability afforded by each strategy. The process of cremation, whether for scattering, storage in a columbarium niche, or forest burial, is still an energy-intensive process that releases harmful pollutants into the air such as carbon monoxide, soot, sulfur dioxide, and mercury emissions (Coutts, Basmajian, \& Chapin, 2011, p. 254; Calderone, 2015; Blakemore, 2016). Through grave reuse, future burials can be accommodated through downward rather than outward growth. However, as a variant of casket burials, the harmful chemicals and materials from embalming and caskets are still present. Conversely, green or natural burials do not involve embalming or cremation and are more affordable, thus more accessible for low-income individuals. Moreover, some methods explored in the case study may not be as widely accepted in Toronto, either for religious reasons (such as cremation) or cultural reasons, as some practices are unprecedented in most parts of North America (such as grave reuse). Green burials were shown to be more successful across these measures when compared to casket burials as well as the other interment methods discussed in the case study. Given these benefits, and the growing popularity of green burial in the west, Toronto's cemetery planning framework should have regard to this cultural practice of interment.

The best practices from each city case study are used to inform the following recommendations for the planning of Toronto's cemeteries. In particular, these recommendations are formed with the goals of creating design guidelines that would enhance cemeteries as open spaces, and a policy framework to facilitate alternatives to casket burials, improve the sustainability of cemeteries, and make access to burial grounds more affordable and equitable. 


\subsection{Recommendations}

\subsection{Policy Amendments}

Evidenced in the case study, political will is a major factor contributing to the planning of cemeteries, which, as discussed above, is lacking in discourse and practice in Toronto. Moreover, Ontario's planning documents do not currently reflect or support alternatives to casket burials as a land use. Through qualitative research, the following policy recommendations reveal the need for planners to amend Ontario's provincial planning framework to recognize cemeteries as a key land use within complete communities and to support more sustainable and equitable alternatives to casket burials. This can be implemented through, yet is not limited to, the following recommendations:

- Update Ontario planning legislation, including the Growth Plan and Official Plan, to be consistent with the 2014 Provincial Policy Statement to include a definition of cemeteries and reference to cemeteries as a component of complete communities in future amendments of these documents.

- The Oak Ridges Moraine Conversation Plan (ORMCP) stipulates that small scale cemeteries are currently allowed on the Countryside Area land designations. However, cemeteries are not permitted on actual Natural Core Areas and Natural Linkage Designations. The Province should and has been encouraged to revisit the restrictions associated with this consideration.

- Amend zoning by-laws to differentiate classifications of cemeteries for green burial lands, scattering gardens, crematoria, etc.

- Encourage municipalities to develop feasibility studies, cemetery master plans and update cemetery needs analyses every 10 years. 
- Encourage cemetery registrars in Ontario to permit an increase in length and width dimensions of graves in order to accommodate multigenerational families within a community.

\subsection{Green Incentive Program}

In the United States, a number of incentive-based approaches have been implemented in order to manage urban growth and protect open spaces. For example, communities may promote infill development and redevelopment by providing subsidized land costs, tax exemptions, reduction of development fees, and other incentives. Public acquisition of land is a frequently used public policy instrument for the protection of open space; at the local up to the federal level, open space is acquired and set aside for the creation or preservation of parks, landscapes, wildlife refuges, and other environmentally sensitive areas (Bengston et al., 2003). Because cemeteries are zoned as open space in Ontario, this green incentive model can be adapted for the creation of new cemeteries away from urban centres. Precedents for this model include Taiwan, where the government subsidized cemetery landscaping projects between 1976 and 1998 (Huang, 2007).

Municipalities can subsidize cemetery operators that allocate a portion of their land and unsold plots for green burials or scattering gardens in order to promote these interment options. The subsidy can then be directed toward the costs of operations, care and maintenance, and social assistance for low-income households who may not otherwise be able to afford a burial. In this model, land use within the cemetery would be 
maximized, while serving a social and environmental benefit: green burials are less impactful on the environment, less costly, and occupy less space than casket burials.

\subsection{Cemetery Design and Public Engagement}

Cemetery planners and landscape architects have adopted several strategies to maximize the amount of developable land within a given site to adjust to physical constraints. Some of these strategies, as discussed in the case study, are to do with the physical capacity of land, while others aim to address public perception of and receptiveness to cemeteries. Reframing cemeteries as historical, cultural, and communal memorial spaces for the living asserts their importance as a vital part of human habitation and complete communities. As one interviewee stated, the public is not always motivated by the positive outcomes of cemeteries, but through design, cemeteries can be made to feel more inviting ${ }^{13}$ :

- Design trails within the cemetery as well as thoroughfares with the surrounding area to ease accessibility.

- Remove harsh barriers such as high fences and opt for hedges or treelines around the perimeter of the cemetery.

- Post signs at entrances outlining permitted rather than prohibited uses.

- Incorporate shade, lighting, gardens, seating and wayfinding/placemaking measures.

- Leave the gates open at night and encourage police to make cemeteries a part of their nightly rounds.

${ }^{13}$ Where culturally appropriate. 
- Educate the public on other means of interment and their potential benefits ${ }^{14}$.

- Educate people about other types of memorialization (other than a headstone), such as plaques, trees, dedicated benches, or celebration of life ceremonies in lieu of grave markers.

- Encourage engaged interaction with cemeteries through guided tours, digital repositories for photographs and obituaries, online memorials, and annual events such as memorial services on Mother's/Father's Days.

\subsection{Cemetery Sustainability}

- Dedicate a portion of cemetery land for green/natural burials and scattering gardens.

- Landscape with sustainable local plants to establish horticultural importance of cemeteries.

- Consider infilling development at under-utilized and at-capacity cemeteries where possible through columbaria.

${ }^{14}$ The funeral business is ultimately a business. Educating the public on alternatives to interment also allows people to be aware of what is and isn't required for a burial, and less likely to be exploited for profit at a time of emotional vulnerability. 


\subsection{Conclusion}

The future of cemetery planning in Toronto, as in many cities, is precarious. Their invisibility, erasure, and complicated history and nature of Ontario's cemeteries, from governance to zoning, makes it difficult for municipalities to plan for cemeteries in Ontario. As cities face a shortage of land for burial grounds, Toronto has yet to develop a viable planning framework to address and accommodate this land use planning uncertainty. The lack of political will and the underrepresentation of cemeteries in mainstream planning discourse furthers this difficulty. As a part of complete communities, planners are also tasked with planning cemeteries to be environmentally sustainable, affordable, and equitable within the constraints of land scarcity.

Globally, cities have employed various tactics to address their land scarcity: Hong Kong and New Delhi have implemented columbaria and other vertical cemeteries; Berlin and Taipei popularized forest burials and scattering grounds through a resurgence of North America's park-like cemetery designs; and Singapore and London have developed ways to free up land through culturally-sensitive grave exhumation and double-depth burials. An analysis of the history, implementation process, and success of these methods reveals lessons to be applied for the future of cemetery planning. In the pursuit a cemetery planning framework for Toronto, this paper has considered municipal subsidy programs, incentive policies, public engagement strategies, and a set of design recommendations based on the analyses of these cities.

Throughout this paper, the role of urban planners as well as municipal and provincial governments has been underscored as a necessary component in realizing the success of any such undertakings. In order to adequately address the problems facing 
our cemeteries, these landscapes must be recognized as an important land use as well as an equity and sustainability issue. Cemeteries cannot be rendered as invisible and forgotten spaces, as they have been, for any longer, but rather must be asserted as a significant land use and part of a complete community. 
6.0 Appendices

Appendix 1. Map of Toronto's Cemeteries

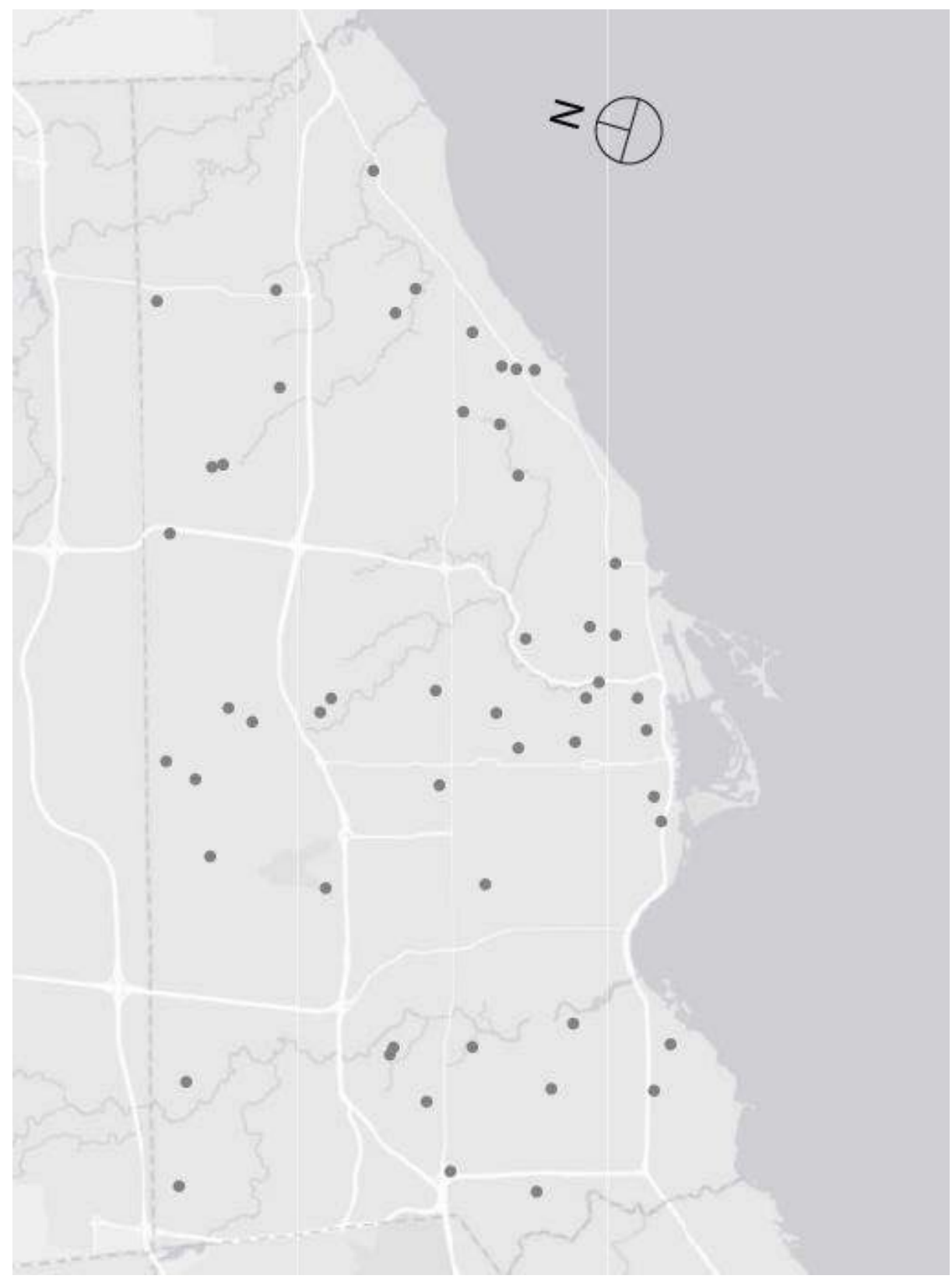




\section{Appendix 2. Subject Matter Expert Interview Questions}

1. What are some of the key barriers within the cemetery planning process and the creation of new cemeteries?

2. What, if any, considerations are being made within the cemetery planning process with regards to land constraints?

3. What, if any, considerations are being made within the cemetery planning process with regards to environmental sustainability?

4. What, if any, considerations are being made within the cemetery planning process with regards to social equity?

5. How do(es) you/your organization engage the public in the cemetery planning process?

6. Should cemeteries be planned and designed to promote use outside of visitations? How can this be accomplished?

7. How are trends in interment practices reflected in cemetery planning and design?

8. Is there anything we have not discussed that you would like to be discussed in this study? 


\subsection{Bibliography}

Au-Yong, R. (2017 July 19). Size of Choa Chu Kang Cemetery to be cut by one-third to make way for Tengah expansion. The Straits Times. Retrieved from https://www.straitstimes.com/singapore/size-of-choa-chu-kang-cemetery-to-becut-by-one-third

Basmajian, C., \& Coutts, C. (2010). Planning for the Disposal of the Dead. Journal of the American Planning Association. 76(3). 305-317.

Babic, D., \& Bingula, M. (2015). Interpretation at special places: Mirogoj Cemetery. Heritage as an alternative driver for sustainable development and economic recovery in South East Europe. Procedia - Social and Behavioural Sciences, 188, p. 186-192.

Bawden, T. (2014 November 07). The London cemetery pioneering the reuse of its much-needed burial plots. The Independent. Retrieved from https://www.independent.co.uk/environment/the-london-cemetery-pioneering-thereuse-of-its-much-needed-burial-plots-9847672.html

Belford, T. (2018, April 19). For cemeteries, it's all about the land. The Globe and Mail. Retrieved from https://www.theglobeandmail.com/report-on-business/forcemeteries-its-all-about-the-land/article996739/

Bennett, G. \& Davies, P. J. (2015). Urban cemetery planning and the conflicting role of local and regional interests. Land Use Policy, 42. 450-459.

Bereavement Authority of Ontario. (2016). About the BAO. Retrieved from https://thebao.ca/home/about-the-bao/

Berlin Population. (2018 October 19). Retrieved from http://worldpopulationreview.com/world-cities/berlin-population/

Blakemore, E. (2016 February 01). Could the Funeral of the Future Help Heal the Environment? Smithsonian. Retrieved from https://www.smithsonianmag.com/science-nature/could-funeral-future-help-healenvironment-180957953/

Blundy, R. (2017 July 15). Why dying in Hong Kong is getting more complicated...and expensive. South China Morning Post. Retrieved from https://www.scmp.com/news/hong-kong/educationcommunity/article/2102544/why-dying-hong-kong-getting-more-complicated-and 
Brown, T. (2013). The making of urban 'healtheries': the transformation of cemeteries and burial grounds in late-Victorian East London. Journal of Historical Geography, 42, pg. 12-23.

Calderone, J. (2015 November 04). Burying dead bodies takes a surprising toll on the environment. Business Insider. Retrieved from https://www.businessinsider.com/burying-dead-bodies-environment-funeralconservation-2015-10

Campo-Ruiz, I. (2015). Equality in death: Sigurd Lewerentz and the planning of Malmo Eastern Cemetery 1916-1973. Planning Perspectives, 30(4). 639-657.

Carrington, D. (2016 May 06). Re-using graves means UK cemetery will never run out of space. The Guardian. Retrieved from https://www.theguardian.com/environment/2016/may/06/re-using-graves-meansuk-cemetery-will-never-run-out-of-space

CBC News. (2005 April 13). Singapore recycling graves as space-saving measure. CBC News. Retrieved from https://www.cbc.ca/news/world/singapore-recyclinggraves-as-space-saving-measure-1.529634

Cemeteries Act (Revised), R.S.O. (1990, c. C.4). Retrieved from https://www.ontario.ca/laws/statute/90c04

Census and Statistics Department: Government of the Hong Kong Special Administrative Region. (2019, February 21). Hong Kong Statistics: Population. Retrieved March 8, 2019, from https://www.censtatd.gov.hk/hkstat/sub/so20.jsp

Chandran, R. (2019 January 03). No rest for the dead: Singapore digs up graves for highways. Reuters. Retrieved from https://www.reuters.com/article/us-singaporelandrights-cemetery/no-rest-for-the-dead-singapore-digs-up-graves-for-highwaysidUSKCN1OXOMM

Chase, J. (2015 October 28). R.I.P. Berlin: Face your ghosts and tour the city's cemeteries. Deutsche Welle. Retrieved from https://www.dw.com/en/rip-berlinface-your-ghosts-and-tour-the-citys-cemeteries/a-18758516

Chen, X., Yang, K. (2015). Analysis on Establishing Urban Cemetery Planning and Compiling System. Asian Agricultural Research, 7(4). 55-57.

City of Hamilton, Staff Report. (2015). City of Hamilton Cemeteries: Business Plan Strategy \& Land Needs Assessment (PW15075) - (City Wide). City of Hamilton: Public Works Department, Environmental Services Division. 
City of Toronto, Zoning By-law No. 569-2013. Chapter 90.70 Open Space - Cemetery Zone. (December 20, 2017).

Clayden, A., Green, T., Hockey, J., \& Powell, M. (2018). Cutting the lawn - Natural burial and its contributions to the delivery of ecosystem services in urban cemeteries. Urban Forestry \& Urban Greening, 33, p. 99-106.

Cohen, D. (2019 February 08). Britain's burial crisis - and how to solve it. Financial Times. Retrieved from https://www.ft.com/content/88bdc01c-29a0-11e9-a5abff8ef2b976c7

Coutts, C., Basmajian, C., Chapin, T. (2011). Projecting landscapes of death. Landscape and Urban Planning, 102. 254-261.

Coutts, S. (1986). Easeful Death in Toronto: A History of Mount Pleasant Cemetery. Society for the Study for Architecture in Canada Bulletin, 11(3), pg. 8-10.

Cremation Association of North America. (2019). Industry Statistical Information Cremation Association of North America (CANA). [online] Retrieved from: https://www.cremationassociation.org/page/IndustryStatistics [Accessed 4 Mar. 2019].

Davies, P. J. \& Bennett, G. (2016). Planning, provision and perpetuity of deathscapes Past and future trends and the impact for city planners. Land Use Policy, 55. 98107.

de Sousa, A. N. (2015 January 21). Death in the city: what happens when all our cemeteries are full? The Guardian. Retrieved from https://www.theguardian.com/cities/2015/jan/21/death-in-the-city-what-happenscemeteries-full-cost-dying

Delhi Population. (2018 October 26). Retrieved from http://worldpopulationreview.com/world-cities/delhi-population/

Desmond, P. (2013, August 17). Perpetual care? Cities struggle to meet public expectations on cemetery maintenance. The Record. Retrieved from https://www.therecord.com/news-story/4036717-perpetual-care-cities-struggle-tomeet-public-expectations-on-cemetery-maintenance/

Evansen, K. H., Nordh, H., \& Skaar, M. (2017). Everyday use of urban cemeteries: A Norwegian case study. Landscape and Urban Planning, 159, p. 76-84.

Elliott, R. (2018 July 13). Densifying Death and High-Rise Cemeteries. The Urban Developer. Retrieved from https://theurbandeveloper.com/articles/vertical-highrise-cemeteries 
Everington, K. (2018 August 10). 2 days before Ghost Month, Taiwan approves solar panels in cemeteries. Taiwan News. Retrieved from https://www.taiwannews.com.tw/en/news/3503707

Finney, P. J. (2012). Landscape Architecture and the "Rural" Cemetery Movement. Center for Research Libraries, 31(4). Retrieved from https://www.crl.edu/focus/article/8246

Funeral, Burial and Cremation Services Act (2002, S.O. 2002, c. 33). Retrieved from https://www.ontario.ca/laws/statute/02f33

Gorvett, Z. (2017 November 28). The Buildings Designed to House the Dead. BBC. Retrieved from http://www.bbc.com/future/story/20171127-the-buildingsdesigned-to-house-the-dead

Government of Canada. (2018). Funding and incentive programs for greening your business. Retrieved from https://canadabusiness.ca/managing-yourbusiness/day-to-day-operations/environment-and-business/funding-andincentive-programs-for-greening-your-business/

Green Burial Society of Canada. (2015, April 15). What is Green Burial? Retrieved from http://www.greenburialcanada.ca/greenburial

Greenbelt Plan. (2017). S.3.1.4. Retrieved from http://www.mah.gov.on.ca/Page13783.aspx

Growth Plan for the Greater Golden Horseshoe. (2017). R.S.O. Retrieved from http://placestogrow.ca/index.php?option=com content\&task=view\&id=9\&ltemid= $\underline{12}$

Hariyono, W. P. (2015). Vertical Cemetery. Procedia Engineering, 118, p. 201-214.

Hong Kong Population. (2018 September 24). Retrieved from http://worldpopulationreview.com/countries/hong-kong-population/

Huang, L. S. (2007). Intentions for the Recreational Use of Public Landscaped Cemeteries in Taiwan. Landscape Research, 32, (2), p. 207-223.

Joshi, M. (2018 June 25). Grave concerns: As population increases, space to bury the dead is fast shrinking. The Indian Express. Retrieved from https://indianexpress.com/article/cities/delhi/grave-concerns-5024790/

Kong, L. (2012). No Place, New Places: Death and its Rituals in Urban Asia. Urban Studies, 49(2), 415-433. 
Krause, R. (2015 April 02). Going green - also in death. Deutsche Welle. Retrieved from https://www.dw.com/en/going-green-also-in-death/a-18359592

Larkin, M. T. (2011). An Analysis Of Land Use Planning Policies For Cemeteries In Ontario. Theses and dissertations. Paper 1550.

Lehrer, J. D. (1974). Cemetery Land Use and the Urban Planner. Journal of Urban and Contemporary Law, 7. 181-197.

Liu, L. J. \& Liu, K. L. (2018 April 05). Eco-friendly burials growing trend in Taiwan. Focus Taiwan. Retrieved from http://focustaiwan.tw/news/asoc/201804050009.aspx

London Population. (2018 November 21). Retrieved from http://worldpopulationreview.com/world-cities/london-population/

McIntyre, G. (2017 March 15). Mountain View Cemetery's grave ready for family's third generation. Vancouver Sun. Retrieved from https://vancouversun.com/news/local-news/mountain-view-cemeterys-graveready-for-familys-third-generation

McManus, J. (2015 March 13). The world is running out of burial space. BBC. Retrieved from https://www.bbc.com/news/uk-31837964

McMillan, S. T. (2016 August 05). In Germany, some cemeteries are being turned into parks, playgrounds and gardens. Public Radio International. Retrieved from https://www.pri.org/stories/2016-08-05/germany-some-cemeteries-are-beingturned-parks-playgrounds-and-gardens

Oak Ridges Moraine Conservation Plan. R.S.O. (2002). C. 40, s.1. Retrieved from http://www.mah.gov.on.ca/Page1707.aspx

Paul, C. (2017 January 11). Are German cemeteries dying out? Deutsche Welle. Retrieved from https://www.dw.com/en/are-german-cemeteries-dying-out/a$\underline{41200038}$

Plenke, M. (2016 April 07). Traditional burials are ruining the planet — here's what we should do instead. Business Insider. Retrieved from https://www.businessinsider.com/traditional-burials-are-ruining-the-planet-2016-4

Ponciano, C. (2018, February 10). Green burials cheaper and legal, says funeral director. CBC. Retrieved from https://www.cbc.ca/news/canada/kitchenerwaterloo/green-burials-waterloo-region-1.4526427 
Provincial Policy Statement. (2014). S.1.1.1.b. Retrieved from http://www.mah.gov.on.ca/page10679.aspx

Relyea, D. E. (2013). Guidelines to Enhance the Ecological Value of Cemeteries in Southern Ontario. (Unpublished master's thesis). University of Guelph, Guelph, Ontario.

Rugg, J. \& Holland, S. M. (2017). Respecting corpses: The ethics of grave re-use. Mortality, p. 1-14.

Singapore Population. (2018 October 01). Retrieved from http://worldpopulationreview.com/countries/singapore-population/

Singh, D. (2015 May 31). Delhi's cremation crisis: Activists call for change as traditional - and polluting - crematoriums burn through lakhs of trees, Daily Mail India. Retrieved from https://www.dailymail.co.uk/indiahome/indianews/article3104950/Delhi-s-cremation-crisis-Activists-call-change-traditional-pollutingcrematoriums-burn-lakhs-trees.html

Singh, P. \& Manohar, M. (2018, August 28). Nearly 4 lakh trees lost to cremations every year, but Delhi finds it tough to make green shift. India Times. Retrieved from https://timesofindia.indiatimes.com/city/delhi/nearly-4l-trees-lost-to-cremationsevery-year-but-delhi-finds-it-tough-to-make-green-shiftlarticleshow/65568463.cms

Steger, I. (2019 March 13). In land-scarce Taipei, the True Dragon Tower is a vertical home for the dead. Quartz. Retrieved from https://qz.com/13744887/taipeisdragon-tower-provides-alternative-form-of-burial/

The Straits Times. (2017 November 23). How graves are exhumed. The Straits Times. Retrieved from https://www.straitstimes.com/singapore/how-graves-are-exhumed

Taipei Population. (2018 December 04). Retrieved from http://worldpopulationreview.com/world-cities/taipei-population/

Teather, E. K. (1998). Themes from Complex Landscapes: Chinese Cemeteries and Columbaria in Urban Hong Kong. Australian Geographical Studies, 36(1), p. 2136.

Teather, E. K. (1999). High-Rise Homes for the Ancestors: Cremation in Hong Kong. The Geographical Review, 89 (3), p. 409-430.

Teo, P.; Yeoh, B. S. A.; Ling, O. G.; \& Lai, K. P. Y. (2004). Landscapes of Death: Cemeteries, Crematoria and Columbaria in Changing Landscapes of Singapore. McGraw-Hill: Singapore, p. 196-211. 
Toronto Population. (2018 December 27). Retrieved from http://worldpopulationreview.com/world-cities/toronto-population/

Walker, T. (2016 September 6). The green way of death. Deutsche Welle. Retrieved from https://www.dw.com/en/the-green-way-of-death/a-19527764 


\section{Images}

1. Bain News Service, P. (ca. 1910) Midday in St. Paul's churchyard, New York. , ca. 1910. [Between and Ca. 1915] [Photograph] Retrieved from the Library of Congress, https://www.loc.gov/item/2014699365/.

2. Historic St. Luke's Church, ca. 1957. [Photograph] Retrieved from Historic St. Luke's Church, http://historicstlukes.org/ancient-cemetery/

3. Yarkon Cemetery, Tel Aviv, 2014. [Photograph]. Retrieved from Darren Boyle, Daily Mail UK. https://www.dailymail.co.uk/news/article-2797118/cities-dead-israelturns-high-rises-cemeteries-approval-rabbis-artificial-caves.html

4. Graves cover a hillside in front of apartment buildings in Hong Kong, 2015. [Photograph]. Retrieved from Kelvin Chan, Asia Pacific. https://www.japantimes.co.jp/news/2015/12/06/asia-pacific/social-issues-asiapacific/crowded-hong-kong-has-little-space-for-the-dead/\#.XJzzzJhKhPY

5. 3rd Columbarium, 2016. [Photograph] Retrieved from Construction Plus Asia, http://www.constructionplusasia.com/hk/3rd-columbarium/

6. Po Fook Hill Columbarium, 1990. [Photograph]. Retrieved from Po Fook Hill. https://ashes.pofookhill.com/en/

7. St. Thomas Christian Cemetery, Tughlakabad, 2015. [Photograph]. Retrieved from Gajendra Yadav, The Indian Express. https://indianexpress.com/article/cities/delhi/at-tughlakabad-asias-largest-verticalcemetery-cemetery-looks-upward-for-burial-space/

8. A pupil at the Sophienkirche daycare climbs atop a gravestone in the center's playground, 2016. [Photograph]. Retrieved from Shane Thomas McMillan, PRI. https://www.pri.org/stories/2016-08-05/germany-some-cemeteries-are-beingturned-parks-playgrounds-and-gardens

9. Graves are marked for possible reclamation in London City Cemetery, 2014. [Photograph]. Retrieved from Dan Kitwood, The Independent. https://www.independent.co.uk/environment/the-london-cemetery-pioneering-thereuse-of-its-much-needed-burial-plots-9847672.html 